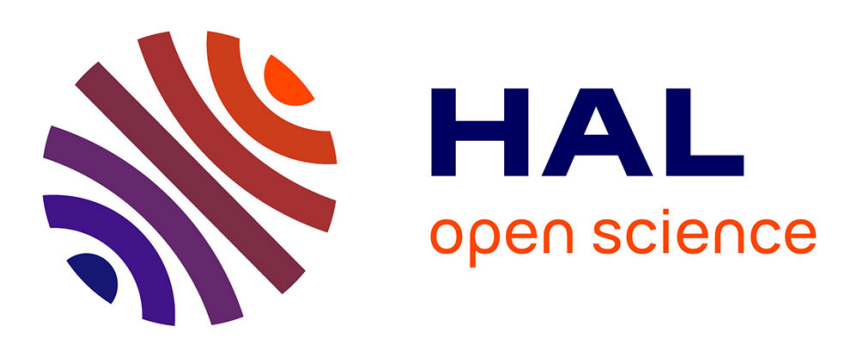

\title{
Discovery of a subnanomolar and selective spirocyclic agonist of the glucocorticoid receptor
}

Eduard Badarau, Frédéric Robert, Stéphane Massip, Florian Jakob, Simon

Lucas, Sven Frormann, Léon Ghosez

\section{To cite this version:}

Eduard Badarau, Frédéric Robert, Stéphane Massip, Florian Jakob, Simon Lucas, et al.. Discovery of a subnanomolar and selective spirocyclic agonist of the glucocorticoid receptor. European Journal of Medicinal Chemistry, 2019, 161, pp.354-363. 10.1016/j.ejmech.2018.10.032 . hal-02378450

\author{
HAL Id: hal-02378450 \\ https://hal.science/hal-02378450
}

Submitted on 20 Jan 2021

HAL is a multi-disciplinary open access archive for the deposit and dissemination of scientific research documents, whether they are published or not. The documents may come from teaching and research institutions in France or abroad, or from public or private research centers.
L'archive ouverte pluridisciplinaire $\mathbf{H A L}$, est destinée au dépôt et à la diffusion de documents scientifiques de niveau recherche, publiés ou non, émanant des établissements d'enseignement et de recherche français ou étrangers, des laboratoires publics ou privés. 


\title{
Discovery of a subnanomolar and selective spirocyclic ligand of the glucocorticoid receptor
}

\section{Eduard Badarau, ${ }^{\mathrm{a}, \mathrm{b}}$ Frédéric Robert, ${ }^{\mathrm{c}}$ Stéphane Massip, ${ }^{\mathrm{a}}$ Florian Jakob, ${ }^{\mathrm{d}}$ Simon Lucas, ${ }^{d}$ Sven Frormannd and Léon Ghosez ${ }^{* a}$}

${ }^{a}$ Univ. Bordeaux, European Institute of Chemistry and Biology (IECB), 2 Rue Robert Escarpit, 33607 Pessac, FRANCE.

${ }^{b}$ Univ. Bordeaux, Institute of Chemistry \& Biology of Membranes \& Nano-objects (CBMN), Allée Geoffroy Saint Hilaire, Bât B14, 33600 Pessac, FRANCE.

${ }^{c}$ Univ. Bordeaux, Institute of Molecular Sciences (ISM), Bâtiment A12, 351 cours de la Libération 33405 TALENCE Cedex, FRANCE.

${ }^{d}$ Grunenthal GmbH, Zieglerstr. 6, 52078 Aachen, GERMANY

\begin{abstract}
Pure diastereomeric spirocyclic analogs of fluorocortivazol were conveniently prepared by a short and efficient synthetic sequence recently developed in our laboratory. The structures and conformations of several key products were confirmed by single crystal X-ray diffraction analysis. Conformational assignments were also supported by DFT calculations. Preliminary biological testing led to the identification of a highly potent hGR ligand with an excellent activity in the subnanomolar range. All tested compounds from this series were also selective versus the progesterone receptors.
\end{abstract}

\section{Introduction}

Glucocorticoids (GCs) are potent therapeutic agents currently used for the treatment of allergic and inflammatory diseases. The currently accepted paradigm is that the therapeutic benefit of glucocorticoids is highly correlated with their transrepression versus transactivation effects. Transrepression occurs when the complex of GCs and their receptors (GR) inhibits post-transcriptional activity of other transcriptional factors, such as activator protein 1 (AP-1) and the nuclear factor-kappa $\mathrm{B}(\mathrm{NF} \kappa \mathrm{B})$ which are known to induce inflammatory effects. On the contrary, transactivation will trigger undesired side effects. Moreover GCs also interact with many other steroid receptors (MR - mineralocorticoid, PR progesterone, ER - estrogen, AR - androgen receptors) thus leading to other side effects. Developing selective GR ligands with a better dissociating profile would certainly be of therapeutical benefit.

We recently designed a new class of potential ligands of glucocorticoid receptors ${ }^{1}$ which are spirocyclic analogs of the compounds MK disclosed by Ali et al. ${ }^{2}$ (Scheme 1). The spirocyclic substructure was expected to increase the conformational pool while keeping the key hydroxyl pharmacophore in the same environment, as indicated by the good superposition of the reference MK molecule on the spirocyclic target (Figure 1).

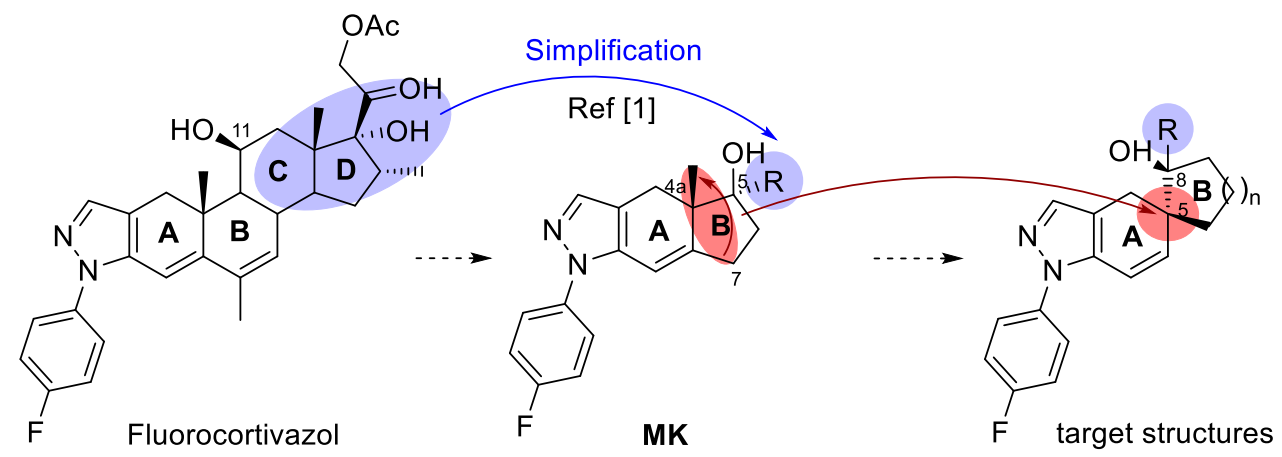

Scheme 1. Design of new potential spiro-corticoids 


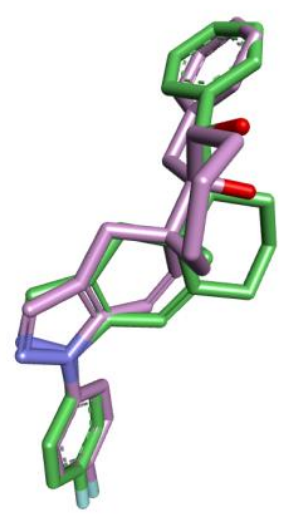

Figure 1. Example of superposition between the reference ligand $M K$ (green) and a designed spirocyclic derivative $($ violet, $n=2, R=B n$ )

Earlier examples of spirocyclic corticoids did not imply a modification of the core scaffold but consisted in the replacement of a carbonyl group by a spirolactone aiming at producing potent aldosterone antagonists devoid of undesired endocrinological side effects. These derivatives were highly potent binders for the MR, AR and $\mathrm{PR}^{3}$ but they bound weakly to the GR. ${ }^{4}$

We have recently reported a detailed study of a practical synthetic route to this new class of spirocyclic ligands. The observation of an $\mathrm{IC}_{50}$ of $27 \mathrm{nM}$ for a representative example in this series prompted us to prepare more examples and study their biological activities in more details. ${ }^{1}$

\section{Results and discussion}

\subsection{Synthesis of the target alcohols}

We had already optimized the synthetic route for the 5- and 6-membered analogues. ${ }^{1}$ We were also interested in testing the higher homologues which should show a higher conformational flexibility, possibly favouring a better interaction with the target protein. The synthetic route was similar to that reported for the lower homologues (Scheme 2). The commercially available cycloheptanone was formylated by treatment with sodium hydride and ethyl formate in dry diethyl ether. Base-catalyzed addition of $\mathbf{1}$ to methyl vinyl ketone followed by treatment of the Michael adduct $\mathbf{2}$ with a 1:1 mixture of morpholine and acetic acid delivered the desired spirocyclic intermediate $\mathbf{3}$. The selective protection of the saturated ketone was first conducted under the experimental conditions optimized for the 6-membered analogue: treatment of $\mathbf{3}$ with ethylene glycol in the presence of 1 eq. PTSA and of molecular sieves at room temperature. This gave a poor yield $(\approx 10 \%)$ of the desired monoketal 4 while the lower homologue had led to a $72 \%$ yield in the same experimental conditions. A slightly better yield (25\%) of 4 was obtained after treatment of $\mathbf{3}$ in a refluxing mixture of ethylene glycol/benzene (Dean-Stark) containing 0.05 eq. of PTSA.

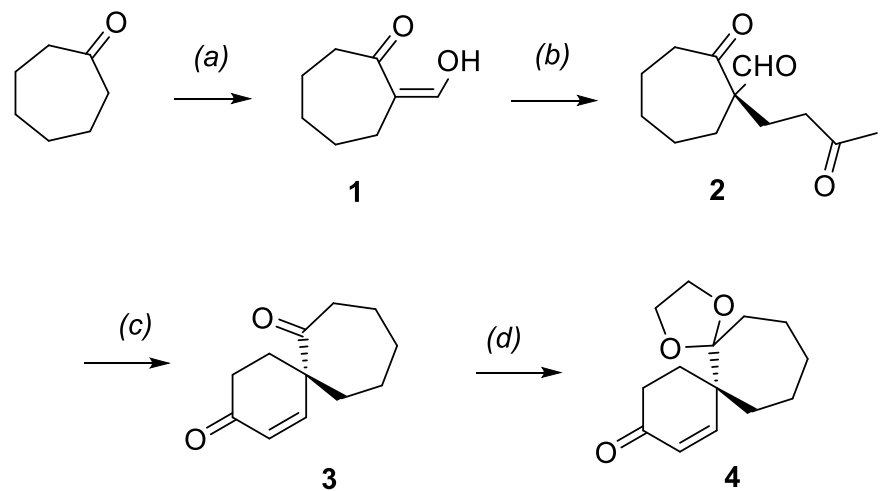

Scheme 2. Synthesis of the spirodiketones 5. NaH, HCOOEt in Et2O, 48 h, rt ; (b) methyl vinyl ketone, DBU, TEA / THF, 12 h, rt, n= 3, 91\%; (c) morpholine : AcOH (1:1) / DMSO, 24 h, rt, $63 \%$; (d) ethylene glycol, PTSA (0.05 eq.) / PhH / 12 h, reflux, $5 \mathrm{c}(25 \%)$; 
The construction of the pyrazole ring was performed in two steps: formylation of the protected ketone 4 followed by treatement with $p$-fluorophenyl hydrazine to yield the tricyclic pyrazole 6 in $72 \%$ yield (Scheme 3). Hydrolysis of 6 delivered ketone $7 \mathbf{c}$ in a good $83 \%$ yield.

A comparative DFT conformational analysis (M06-2X/6-311+G(2d,p) level in chloroform) was performed on the homologous series of ketones $7(n=1,2$ and 3). Contrarily to the 6-membered derivative which has two low-energy conformations in a $1: 1$ ratio, ${ }^{1}$ for the more rigid five-membered ketone 7a (Figure 2) the major (73\%) conformation resembles that of the six-membered ketone in the crystal. Surprisingly, the seven-membered ketone 7c (Figure 2) exhibited a preference (68\%) for a twistboat conformation rather than the expected twist-chair. ${ }^{5,6}$ The full details of the conformational analyses are described in the supplementary material.<smiles>O=C1C=CC2(CCCCC2)C2(C1)OCCO2</smiles>

(a)<smiles>O=C1C=CC2(CCCCCC2)C2(C1)OCCO2</smiles><smiles>Fc1ccc(N2N=CC3C4C=CC5(CCCCC5)OC43CCCO2)cc1</smiles>

(c)<smiles>O=C1CCCCC12C=CC1CC1C=NN2c1ccc(F)cc1</smiles>

Scheme 3 : Construction of the pyrazole ring. (a) : NaH, HCOOEt, $\mathrm{MeOH} /$ toluene / 48 h, rt; (b) 4-F-Ph-NHNH $2, \mathrm{AcONa}^{-} \mathrm{AcOH} / 24$ h, rt, (over two steps, 6: 64\%); (c) $\mathrm{HCl} / \mathrm{THF} / 1.5 \mathrm{~h}, 65^{\circ} \mathrm{C},(7 \mathrm{c}: 83 \%)$.
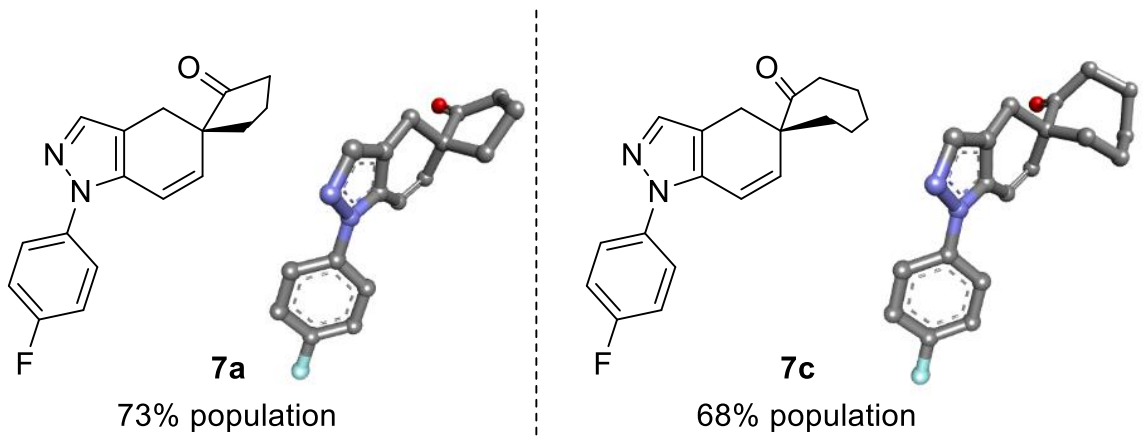

Figure 2 : Conformational analysis of the 5- and 7-membered ketones 10a and 10c

Ketone $\mathbf{7 c}$ and the lower homologs, ketones $\mathbf{7 a}$ and $\mathbf{7 b}$ synthesized as described earlier, ${ }^{1}$ were converted into the target alcohols by addition of phenylmagnesium bromide and benzyl magnesium bromide. The selection of a benzyl and a phenyl group resulted from our previous results, which showed that hydrophobic moieties led to favourable interactions with the GRs. For example, we have previously identified that a benzyl moiety triggered an $\mathrm{IC}_{50}$ of $27 \mathrm{nM}$ in the case of the 6-membered analogue.

The addition reactions yielded mixtures of diastereoisomeric alcohols, which could be separated. (Scheme 4, Table 1). At this stage the formation of two diastereomerss was a bonus since they were easily separated. 

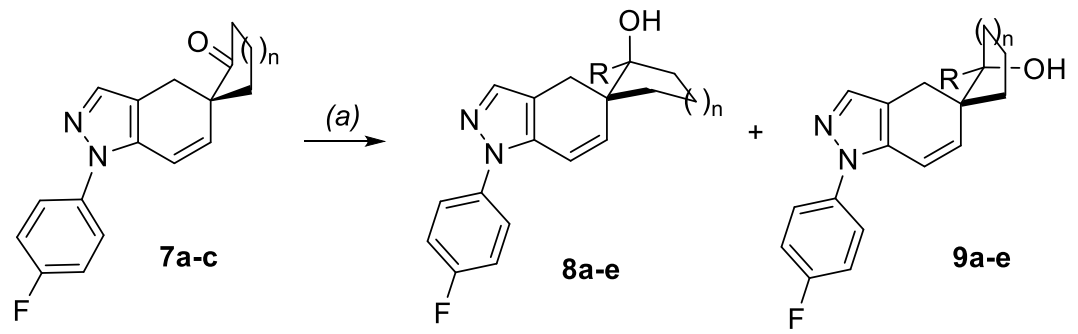

Scheme 4. Reaction of organometallics with ketones 7a-c. (a) RMgBr / THF, $12 \mathrm{~h}, 0^{\circ} \mathrm{C}$ to r.t. (see Table $\mathbf{1}$ for details)

Table 1. Reaction of organometallics with ketones $\mathbf{1 0}$

\begin{tabular}{cccc}
\hline $\mathbf{n}$ & $\mathbf{R}$ & \multicolumn{2}{c}{ Diastereoisomers $^{\mathbf{c}}$} \\
\hline 1 & $\mathrm{Ph}$ & $\mathbf{8 a}(12 \%)$ & not isolated \\
2 & $\mathrm{Ph}$ & $\mathbf{8 b}(56 \%)$ & 9b $(27 \%)$ \\
2 & $\mathrm{Bn}^{1}$ & $\mathbf{8 c}(81 \%)$ & 9c $(13 \%)$ \\
3 & $\mathrm{Ph}$ & $\mathbf{8 d}(10 \%)$ & 9d $(38 \%)$ \\
3 & $\mathrm{Bn}$ & $\mathbf{8 e}(20 \%)$ & 9e $(18 \%)$ \\
\hline
\end{tabular}

In our previous report ${ }^{1}$ we had assigned the preferred conformations of diastereoisomeric alcohols 8 and 9 by DFT calculations. The conformational assignment was also supported by an X-ray diffraction analysis conducted on only one diastereoisomer $(\mathrm{R}=1$-propynyl). Now we have been able to obtain suitable crystals for both diastereoisomers $8 b$ and $9 b(R=P h)$. Our initial hypothesis concerning the conformation of all diastereoisomers was thus confirmed: an axial hydroxyl group and the bulkier alkyl or aryl substituent in equatorial position (Figure 3). Crystals of 7-membered analogues (8e and 9d) suitable for X-ray diffraction analyses could also be obtained. They also confirmed that both isomers adopt the conformation with an axial hydroxyl group as in the case of the related 5- and 6-membered alcohols (Figure 4).

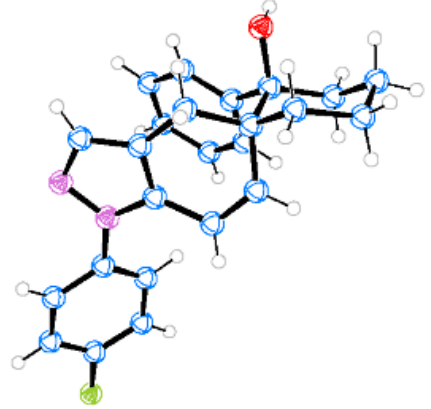

$8 \mathbf{b}$

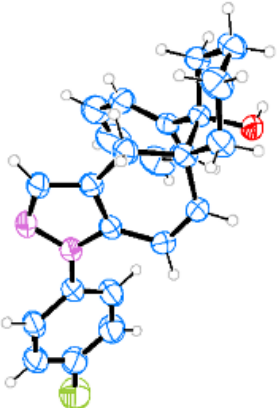

$9 \mathrm{~b}$

Figure 3. Crystal structures of tertiary alcohols $\mathbf{8 b}$ and $\mathbf{9 b}$
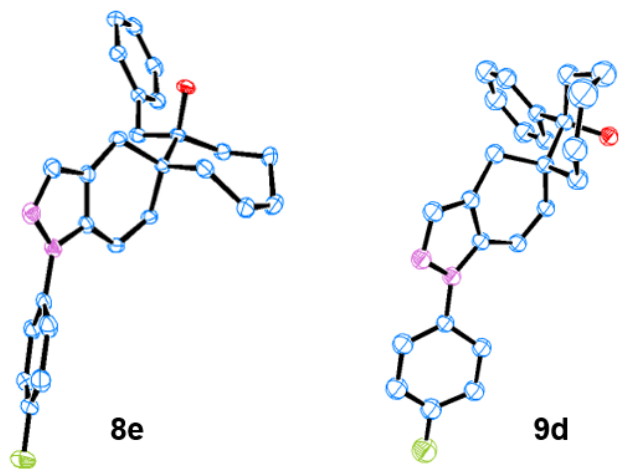

Figure 4. Crystal structures of tertiary alcohols $\mathbf{8 e}$ and $\mathbf{9 d}$ 
The spatial orientation of the hydroxyl group was expected to be an important factor for the interaction with the glucocorticoid receptor. It seemed thus important to confirm that the ligands conserve their conformations in physiological conditions. We therefore studied the conformational profile of the phenyl-substituted tertiary alcohols by DFT in water (M06-2X/6-311+G(2d,p) level). As expected, in both alcohols $\mathbf{8 b}$ and $\mathbf{9 b}$, the favoured conformations were those with an equatorial phenyl group (higher A value: 3 vs $0.87 \mathrm{kcal} / \mathrm{mol}$ ), This conformation was further stabilized as a result of a $\pi$-stacking interaction between the phenyl and pyrazole ring. For $\mathbf{8 b}$ in aqueous solution, $97 \%$ of the conformational population corresponded to conformers with an equatorial phenyl group but differing by the conformation around the N-Ar bond. One of these conformers was found in the crystal structure of $\mathbf{8 b}$. The situation is similar for the other diastereoisomer $\mathbf{9 b}$, the conformers with an equatorial phenyl group representing $90 \%$ of the conformational population (Figure 5). The calculations also revealed some stabilization of these conformers by the $\pi$-stacking between the phenyl group and the pyrazole ring. The same factors were also responsible for the stabilization of the major $(98 \%)$ conformation of the more rigid cyclopentanol 8a. Surprisingly, for the more flexible cycloheptanols 8d and 9d, the more stable twist-chair conformations with an equatorial phenyl group were also predominant (Figure 6).
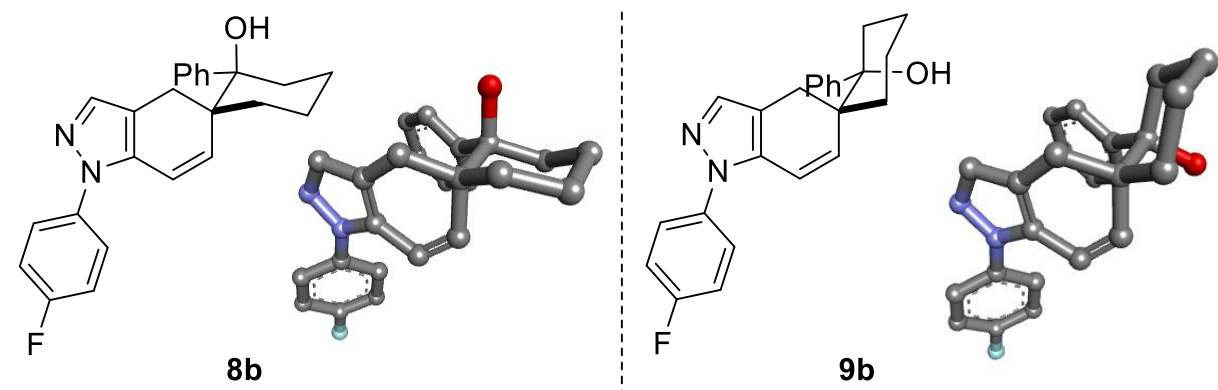

Figure 5. Representative conformers for the alcohols $\mathbf{8 b}$ (97\% population) and $\mathbf{9 b}$ ( $90 \%$ population)
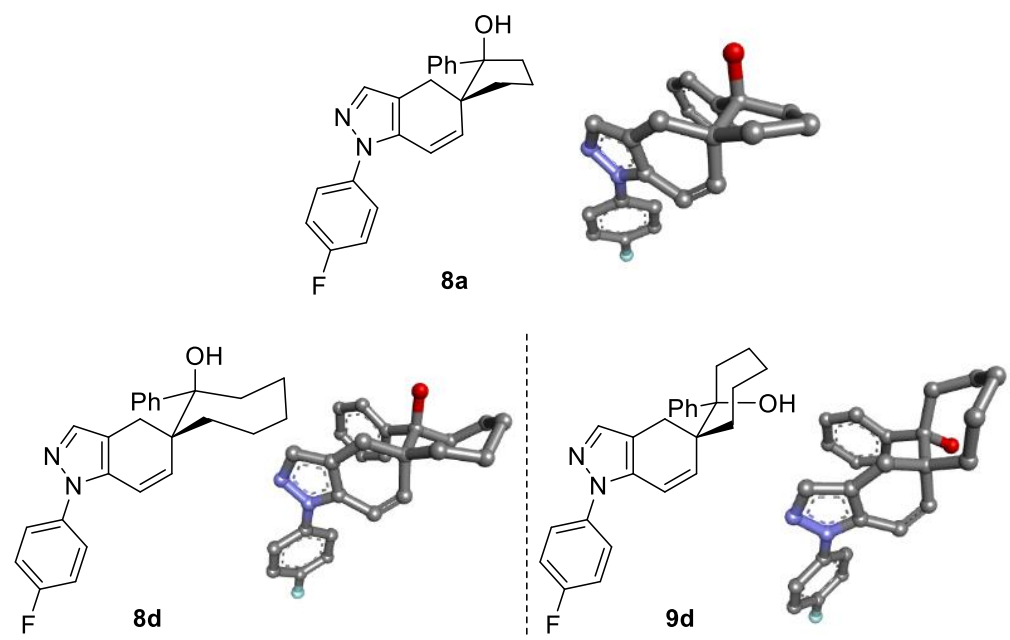

Figure 6. Representative conformers for the alcohols $8 \mathbf{a}$ (98\% population), 9c (97.5\% population) and 9c (97\% population).

\subsection{Synthesis of the dehydrated analogues}

We also synthesized a series of dehydrated analogs to investigate whether the hydroxyl group was essential for the interaction with the GRs. The mixture of diastereomeric alcohols $\mathbf{8 b}$ and $\mathbf{9 b}$ obtained from the reaction of ketone $\mathbf{7 b}$ with phenylmagnesium bromide was treated with triflic acid for $10 \mathrm{~min}$ in refluxing toluene to yield the expected elimination product 10a (Scheme 5). In order to offer a possible additional $\mathrm{H}$-bonding in the binding site, we decided to introduce an $\mathrm{OH}$ group on the aromatic substituent. The reaction of the Grignard reagent derived from 4-bromo-anisole yielded the expected 
alcohol but the subsequent treatment with $\mathrm{BBr}_{3}$ aiming at cleaving the methyl group only yielded the dehydration product 10c. We thus decided to use a trialkylsilyl protecting group which could be easily cleaved under non acidic conditions. It was anticipated that a trimethylsilyl group would not stand the conditions of the first step. We thus selected the more stable triisopropylsilyl (TIPS) ethers. The halogen exchange step with sec-butyl lithium yielded the reactive lithiated nucleophiles. The corresponding diastereomeric mixture of adducts $\mathbf{8}$ and $\mathbf{9}$ was subsequently reacted with TBAF and subsequently with $\mathrm{BBr}_{3}$ to yield the elimination product $\mathbf{1 0 b}$ (Scheme 5).
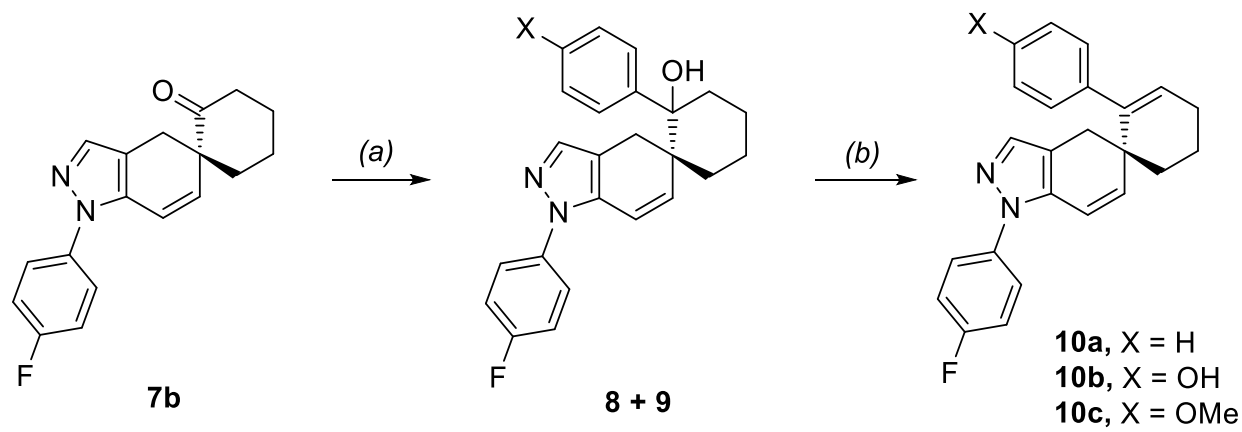

Scheme 5. Synthesis of dehydrated analogues 10a-c. For $\mathbf{X}=\mathbf{H}:(a) \mathrm{PhMgBr} / \mathrm{THF} ;(b) \mathrm{Tf}_{2} \mathrm{O} / \mathrm{PhCH}_{3}, 10$ min, reflux (15\% over two steps); for $\mathbf{X}=\mathbf{O H}:(a)$ 4-OTIPS-bromobenzene, $n$-BuLi; (b) i: TBAF / THF, 5 min, $0^{\circ} \mathrm{C}$; ii: $\mathrm{BBr}_{3} / \mathrm{DCM}, 1 \mathrm{~h}, 0^{\circ} \mathrm{C}(36 \%$ over three steps); for $\mathbf{X}=\mathbf{O M e}$ : (a) 4-OMe-phenylmagnesium chloride / THF, $1 \mathrm{~h}, 0^{\circ} \mathrm{C}$; (b) $\mathrm{BBr}_{3} / \mathrm{DCM}, 1 \mathrm{~h}, 0^{\circ} \mathrm{C}(20 \%$ over two steps).

\subsection{Synthesis of $\alpha$-substituted analogues}

We expected the $\sigma$-position of the ketone $\mathbf{7 b}$ easy to modulate, in spite of the sterical hindrance imposed by the spirocyclic moiety. However, classic anionic conditions employing sodium hydride or LDA (1.2 to 3 eq.) and benzyl bromide as alkylating agents (1.2 to 3 eq.), at low temperature, conducted to full recovery of the starting material. De-aggregating the lithium enolates by coordinating the metal with $N, N^{\prime}$-dimethylpropyleneurea (DMPU), a less toxic equivalent of the well-known coordinating reagent hexamethyl-phosphoramide (HMPA) delivered low yields of the alkylated products along with the recovery of the remaining starting material (Scheme 6). Interestingly, in the case of propargyl bromide, the best experimental conditions were LDA $(1.2 \mathrm{eq})$ in THF at $-78^{\circ} \mathrm{C}$, while adding the DMPU additive showed only traces of the desired product. Surprisingly, dialklylated compounds $\mathbf{1 2}$ were also isolated. They were characterized by NMR, MS and also analysed by X-rays diffraction (Figure 7). The mono$v s$ poly-alkylation issue was discussed by several other groups. ${ }^{7-9}$ It is generally accepted that the enolate reactivity relies on its stage of aggregation, less substituted enolate (thus more aggregated) should be less reactive. The $\pi-\pi$ interaction between the enolate and the alkylating agent could also be an important factor in the polyalkylation process..$^{10}$ 

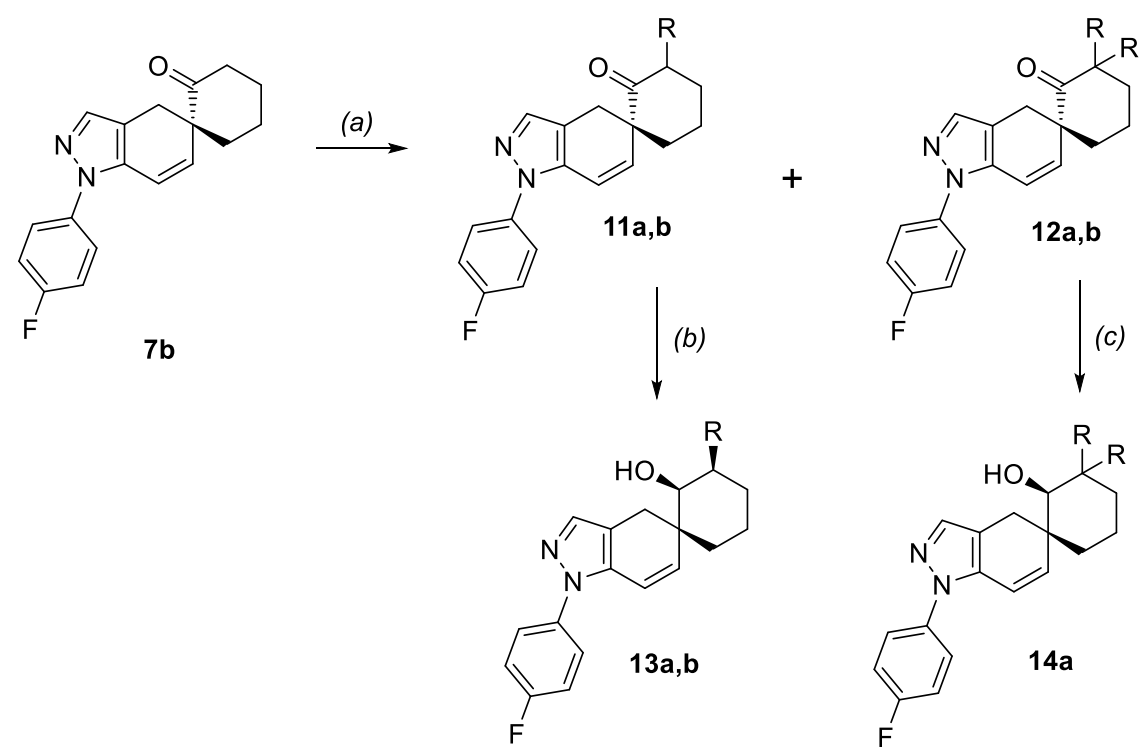

Scheme 6. Synthesis of $\alpha$-substituted analogues 13 and 14. (a) (i) LHMDS (1 eq.), DMPU (1.2 eq.), $\operatorname{BnBr}(1.2 \mathrm{eq}.) / \mathrm{THF}, 12 \mathrm{~h},-78^{\circ} \mathrm{C}$ to r.t. $(\mathrm{R}=\mathrm{Bn}, \mathbf{1 1 a}(12 \%$, isolated as $2 / 1 \mathrm{mix}$ of diastereoisomers), 12a (14\%); (ii) LDA (1.2eq.), propargyl bromide (1.5 eq.) / THF, $12 \mathrm{~h},-$ $78^{\circ} \mathrm{C}$ to r.t. $(\mathrm{R}=$ propargyle, 11b $(18 \%)$, 12b $(10 \%)$; (b) DIBAL-H (3 eq.) / THF, 3 h then recrystallization in $\mathrm{ACN}(\mathrm{R}=\mathrm{Bn}, \mathbf{1 3 a}(55 \%)$; $\mathrm{R}=$ propargyl, 13b (18\%)); (c) LAH (1.2 eq. $) / \mathrm{THF}, 2 \mathrm{~h}, 0^{\circ} \mathrm{C}(\mathrm{R}=\mathrm{Bn}, 56 \%)$.

The structures of diastereoisomer 13a and 13b were confirmed by X-ray diffraction analyses. In both cases the preferred conformation was that with an axial hydroxyl group and an equatorial vicinal substituent (Figure 7).
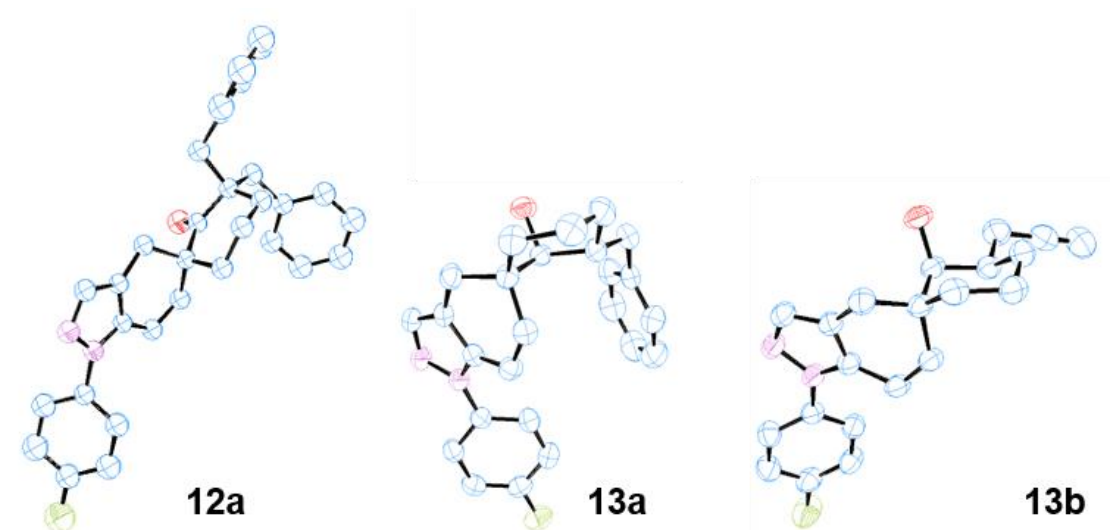

Figure 7. Crystal structures of dibenzylated product 12a and of the isolated reduction products $13 \mathbf{a}$ and 13b. H-atoms were omitted for clarity.

\section{Biological studies}

A study of the binding affinity to the GR was performed using $\left[{ }^{3} \mathrm{H}\right]$ dexamethasone as radioligand (see supporting information for details on binding measurements). It is important to underline that only pure diastereoisomeric alcohols were tested. In most cases their 3D structure was assigned by X-rays diffraction studies (vide supra). As shown in Table 2, a clear trend was observed: compounds having the hydroxyl group parallel to the axis of the central heterocyclic scaffold were all good GR binders with $I C_{50}$ values in the $n M$ range. Except for compound $\mathbf{8 d}$, all other diastereoisomers, which have the hydroxyl moiety orthogonal to the axis of the main scaffold showed a low affinity for the glucocorticoid receptors. The best GR ligand identified in this study was compound $\mathbf{9 b}$ which showed a subnanomolar affinity $\left(\mathrm{IC}_{50}=0.41 \mathrm{nM}\right)$. This derivative was 30 -fold more potent than prednisolone $\left(\mathrm{IC}_{50}=13 \mathrm{nM}\right)$, a classical reference GR ligand used in the same experiment. Increasing the size of the hydroxyl-carrying ring induced a 15-fold decrease of activity. However, the higher homologue 9d still remained a potent hGR ligand $\left(\mathrm{IC}_{50}=6 \mathrm{nM}\right)$. 
Table 2. Binding affinities of the new compounds to the GRs

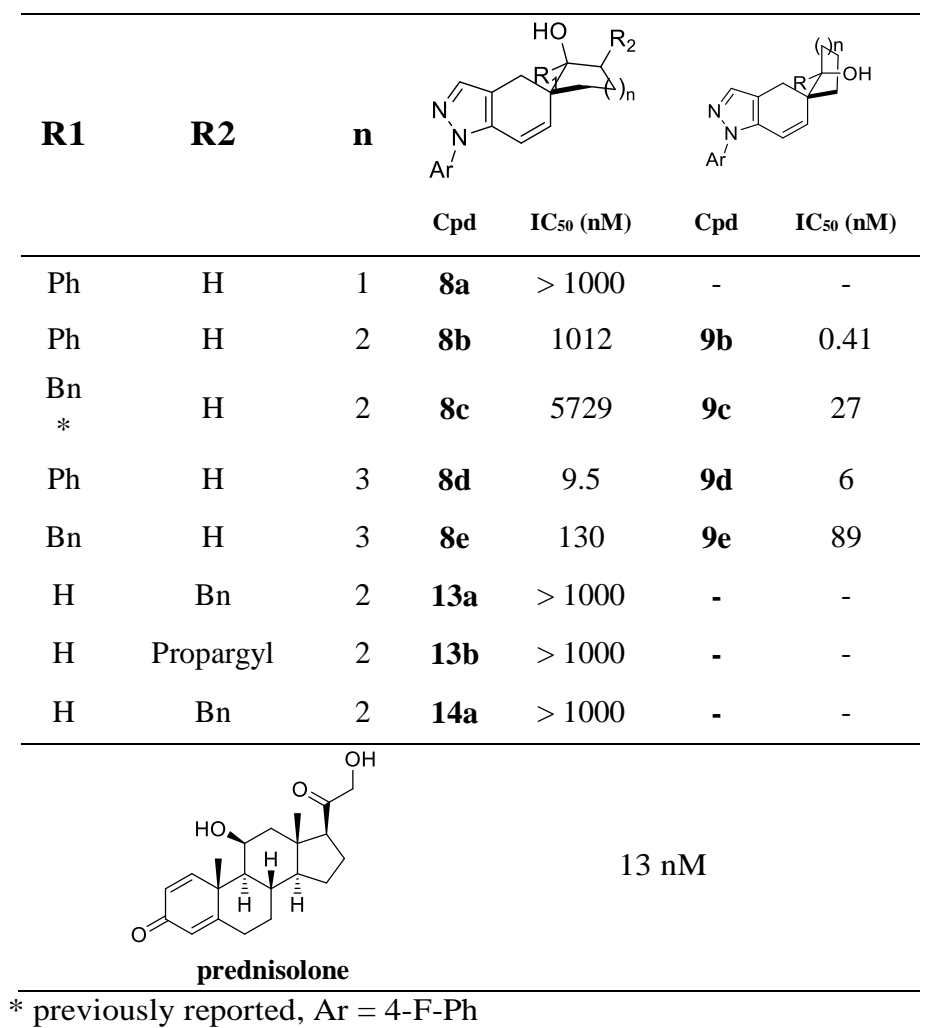

Unexpectedly, even if 50-fold less active than the corresponding tertiary alcohol $\mathbf{9 b}$, the dehydrated compounds 10a,b still showed a binding affinity in the low $\mathrm{nM}$ range (10-20 nM), similar to prednisolone $\left(\mathrm{IC}_{50}=13 \mathrm{nM}\right)($ Table 3). The corresponding methyl ether 10c showed a much weaker activity resulting perhaps from the replacement of $\mathrm{H}$ by a bulkier methyl group. An X-ray diffraction was performed on 10c. Superposition between the crystal structure of $10 \mathbf{c}$ and the crystal structures of the potent derivatives $\mathbf{9 b}$ and 9d shows that all these derivatives share the same aromatic/hydrophobic pharmacophore (Figure 8). In the case of compound 10c, the absence of a hydroxyl group, presumably responsible for a $\mathrm{H}$ bonding within the binding site, decreases its potency 50 -fold for the GRs.

Table 3. Binding affinities to the GRs of the dehydrated compounds 10:

\begin{tabular}{ccc}
\hline $\mathbf{X}$ & $\mathbf{C p d}$ & \\
\hline $\mathrm{H}$ & $\mathbf{1 0 a}$ & 20 \\
$4-\mathrm{OH}$ & $\mathbf{1 0 b}$ & 10 \\
$4-\mathrm{OMe}$ & $\mathbf{1 0 c}$ & 135 \\
\hline
\end{tabular}



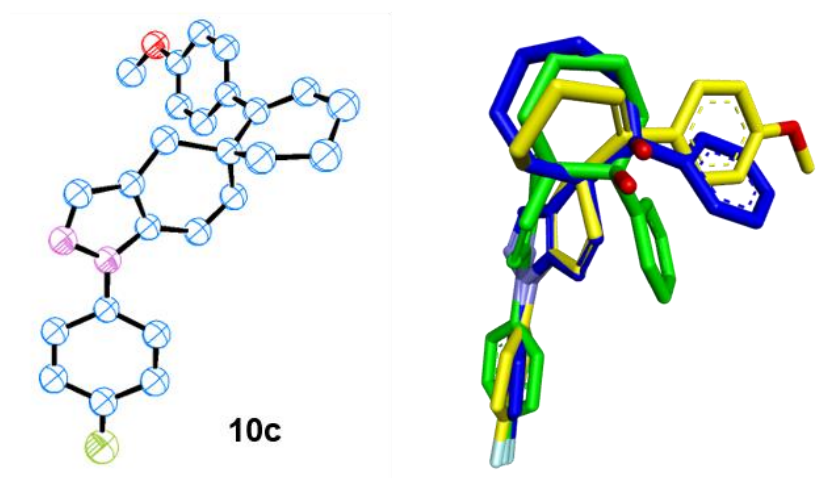

Figure 8 Crystal structure of compound 10c and superposition of crystal structures of $\mathbf{9 b}$ (green), 9d (blue) and 10c (yellow)

A subset of ligands was also evaluated for their binding to the progesterone receptors (PR). As shown in Table 4, these spirocycles were devoid of any affinity for this type of steroid receptors.

Table 4. Affinities for the glucocorticoid and the progesterone receptors

\begin{tabular}{ccc}
\hline Cpd & $\begin{array}{c}\text { IC50 }(\mathbf{n M}) \\
\text { GR }\end{array}$ & $\begin{array}{c}\text { IC50 }(\mathbf{n M}) \\
\text { PR }\end{array}$ \\
\hline $\mathbf{9 b}$ & 0.41 & 780 \\
$\mathbf{9 c}$ & 27 & $>1000$ \\
$\mathbf{9 d}$ & 6 & $>1000$ \\
$\mathbf{1 0 a}$ & 20 & $>1000$ \\
prednisolone & 13 & $>1000$ \\
\hline
\end{tabular}

\section{Conclusions}

Spirocyclic glucocorticoids were designed, synthesized and evaluated for their activity towards hGR. Pure diastereoisomers were tested for their binding to the hGR. This led to the identification of novel highly active glucocorticoid ligands. The best ligand identified so far in this series, compound $\mathbf{9 b}$, had an excellent $\mathrm{IC}_{50}$ of $0.4 \mathrm{nM}, 30$-fold more potent than prednisolone, the classical reference GR ligand used in the same experiment $\left(\mathrm{IC}_{50}=13 \mathrm{nM}\right.$ ). The corresponding diastereoisomer $\mathbf{8 b}$ was devoid of activity for hGR $\left(\mathrm{IC}_{50}=1012 \mathrm{nM}\right)$. Preliminary results also showed that this new class of hGR binders were selective over the PR. The dehydrated analogue (10a) of the most potent compound identified so far (9b) showed a 50-fold lower affinity for the GRs $\left(\mathbf{1 0 b}, \mathrm{IC}_{50}=20 \mathrm{nM}\right)$. This seems to indicate the importance of the H-bond generated by the hydroxyl moiety present on the ligand. However, as the affinity is still in the $\mathrm{nM}$ range, this could be an opportunity for the medicinal chemist to keep essential features for a $\mathrm{nM}$ potency, while removing the chemical complexity represented by an additional asymmetric center.

We believe that these preliminary synthetic and biological studies open a new window for the discovery of new potent and selective glucocorticoid ligands.

\section{References}

(1) Badarau, E.; Robert, F.; Massip, S.; Jakob, F.; Lucas, S.; Frormann, S.; Ghosez, L. Design and Synthesis of Spirocyclic Ligands of Glucocorticoid Receptors. Tetrahedron 2018.

(2) Ali, A.; Thompson, C. F.; Balkovec, J. M.; Graham, D. W.; Hammond, M. L.; Quraishi, N.; Tata, J. R.; Einstein, M.; Ge, L.; Harris, G.; et al. Novel N-Arylpyrazolo[3,2-c]-Based Ligands for the Glucocorticoid Receptor: Receptor Binding and in Vivo Activity. J. Med. Chem. 2004, 47 (10), 2441-2452. 
(3) Nickisch, K.; Bittler, D.; Laurent, H.; Losert, W.; Casals-Stenzel, J.; Nishino, Y.; Schillinger, E.; Wiechert, R. Aldosterone Antagonists. 2. New 7.Alpha.-(Acetylthio)-15,16-Methylene Spirolactones. J. Med. Chem. 1987, 30 (8), 1403-1409.

(4) Claire, M.; Faraj, H.; Grassy, G.; Aumelas, A.; Rondot, A.; Auzou, G. Synthesis of New 11.Beta.-Substituted Spirolactone Derivatives. Relationship with Affinity for Mineralocorticoid and Glucocorticoid Receptors. J. Med. Chem. 1993, 36 (16), 2404-2407.

(5) Bocian, D. F.; Strauss, H. L. Conformational Structure and Energy of Cycloheptane and Some Related Oxepanes. J. Am. Chem. Soc. 1977, 99 (9), 2876-2882.

(6) Dorofeeva, O. V.; Gurvich, L. V.; Mastryukov, V. S. On Conformations of Cycloheptane and Cyclooctane in the Gas Phase. Journal of Molecular Structure 1985, 129 (1), 165-168.

(7) Nicolaou, K. C.; Liu, J.-J.; Yang, Z.; Ueno, H.; Sorensen, E. J.; Claiborne, C. F.; Guy, R. K.; Hwang, C.-K.; Nakada, M.; Nantermet, P. G. Total Synthesis of Taxol. 2. Construction of A and C Ring Intermediates and Initial Attempts to Construct the ABC Ring System. J. Am. Chem. Soc. 1995, 117 (2), 634-644.

(8) Moffat, D.; Nichols, C. J.; Riley, D. A.; Simpkins, N. S. The Synthesis of Bioactive Indolocarbazoles Related to K252a. Org. Biomol. Chem. 2005, 3 (16), 2953-2975.

(9) Streitwieser, A.; Kim, Y.-J.; Ze-Rong Wang, D. Why Is Alkylation of an Enolate Accompanied by So Much Polyalkylation? Org. Lett. 2001, 3 (16), 2599-2601.

(10) Díez-Barra, E.; Merino, S.; Sánchez-Verdú, P.; Torres, J. On the $\pi-\pi$ Interaction in the Benzylation of Ketones. Tetrahedron 1997, 53 (33), 11437-11448.

\section{Experimental}

\subsection{General experimental}

The infrared (IR) spectra were recorded on a Bruker IRFT IFS 55 spectrometer on zinc selenide plates, unless stated otherwise.

${ }^{1} \mathrm{H}-\mathrm{NMR}$ and ${ }^{13} \mathrm{C}-\mathrm{NMR}$ were recorded with Bruker Avance II 300 (at $300.18 \mathrm{MHz}$ and $75.48 \mathrm{MHz}$, respectively) in $\mathrm{CDCl}_{3}-d 1$ and DMSO- $d 6$, using tetramethylsilane (TMS) as an internal standard. Chemical shifts are reported in parts per million (ppm) and the coupling constants are reported in units of Hertz [Hz]. Multiplicities were abbreviated as follows: singlet (s), doublet (d), triplet (t), quartet (q).

Low resolution mass spectra (MS) / High resolution mass spectra (HRMS) were recorded with a ThermoElectron LCQ Advantage and a ThermoElectron Exactive spectrometer, respectively.

Melting points were recorded using a Buchi B-540 apparatus and are uncorrected.

Flash chromatography was performed on Merck 40-70 nM (230-400 mesh) silica gel under air pressure. Thin-layer chromatography (TLC) was carried out on Merck silica gel 60 F254 precoated plates. Visualization was made with ultraviolet light $(\lambda=254 / 365 \mathrm{~nm})$ or using an aqueous potassium permanganate staining solution.

\subsection{Experimental details and characterization data}

\subsubsection{2-oxo-1-(3-oxobutyl)cycloheptanecarbaldehyde (2)}

Sodium hydride (60\% dispersion in mineral oil, $10.5 \mathrm{~g}$ ) was added under nitrogen to dry diethyl ether (400 ml). Subsequently, ethyl formate (11.68 g, $13 \mathrm{ml}, 1.2 \mathrm{eq}$.) and then cyclohexanone (15 g, $12.6 \mathrm{ml}, 1$ eq.) were added and the mixture was stirred for $48 \mathrm{~h}$ at room temperature. The orange mixture was slowly poured on ice-cold water (200 ml), the aqueous layer separated and washed with diethyl ether $(2 \times 200 \mathrm{ml})$ before being acidified with hydrogen chloride (aq. soln., 6N). The organic materials were extracted with diethyl ether $(3 \times 150 \mathrm{ml})$, the combined organic layers were dried over magnesium sulfate and the solvent was evaporated to conduct to the desired $\alpha$-formylated cyclohexanone $\mathbf{1}$ as a light-yellow liquid subsequently used without further purification. The crude compound 1 (18 g, 1 eq.) was dissolved in THF (130 ml), then DBU (2 ml, 0.1 eq.), TEA (2.69 ml, 0.1 eq.) and methyl acrylate $(16.1 \mathrm{ml}, 1.5$ eq.) were consecutively added to the mixture and stirred for $24 \mathrm{~h}$ at room temperature under inert atmosphere. After the complete consumption of the starting material, the solvent was evaporated, the residue diluted with DCM (200 ml) and washed with ammonium chloride (sat. soln., 2 x $100 \mathrm{ml})$ and sodium chloride (sat. soln., 1 x $100 \mathrm{ml}$ ). The organic solvent was dried over magnesium sulfate and evaporated under vacuum. The crude product was purified by flash-chromatography (eluent: PE / EtOAc 7/3) to give the desired addition derivative 2 as a colorless oil $(24.7 \mathrm{~g})$.

$\mathrm{C}_{12} \mathrm{H}_{18} \mathrm{O}_{3}$; Light yellow liquid; Yield: $91 \% ; \mathrm{M}=210.27 \mathrm{~g} / \mathrm{mol}$; IR (ZnSe) $v=2926,1722,1685,1360,1236,1072 \mathrm{~cm}{ }^{-1}$; ${ }^{1} \mathrm{H}$ NMR $\left(300 \mathrm{MHz}, \mathrm{CDCl}_{3}\right) \delta$ 1.47-1.54 (m, 7H), 1.70-2.01 (m, 5H), 2.24-2.54 (m, 5H), $5.82(1 \mathrm{~s}, 1 \mathrm{H}) ;{ }^{13} \mathrm{C} \mathrm{NMR}(75 \mathrm{MHz}$, $\left.\mathrm{CDCl}_{3}\right) \delta 27.4\left(\mathrm{CH}_{2}\right), 28.2\left(\mathrm{CH}_{2}\right), 30.0\left(\mathrm{CH}_{2}\right), 31.3\left(\mathrm{CH}_{2}\right), 33.3\left(\mathrm{CH}_{2}\right), 36.7\left(\mathrm{CH}_{2}\right), 37.2\left(\mathrm{CH}_{2}\right), 40.1\left(\mathrm{CH}_{3}\right), 126.7(\mathrm{CH})$, $172.0\left(\mathrm{C}_{\mathrm{q}}\right), 195.2\left(\mathrm{C}_{\mathrm{q}}\right), 200.1\left(\mathrm{C}_{\mathrm{q}}\right)$; HRMS: calcd. for $\mathrm{C}_{12} \mathrm{H}_{19} \mathrm{O}_{3} 211.13287$, found $211.13289(0.090 \mathrm{ppm})$. 


\subsection{2 spiro[5.6]dodec-4-ene-3,12-dione (3)}

Under inert atmosphere, morpholine ( $9.36 \mathrm{ml}, 1$ eq.) and acetic acid $(6.2 \mathrm{ml}, 1$ eq.) were added to a solution of the previously obtained Michel adduct 2 (22.6 g, 1 eq.) in DMSO (150 ml). The mixture was vigorously stirred overnight at room temperature, then, after the complete consumption of the starting material, slowly added to sodium carbonate (satd. soln., $200 \mathrm{ml})$. The organics were extracted with ethyl acetate $(4 \times 100 \mathrm{ml})$, then washed with ammonium chloride $(150 \mathrm{ml})$ before drying over magnesium sulfate. The solvent was evaporated under reduced pressure and the crude product was purified by flash chromatography (PE / EtOAc 7/3) to give the desired annulated compound $\mathbf{3}(13 \mathrm{~g})$.

$\mathrm{C}_{12} \mathrm{H}_{16} \mathrm{O}_{2}$; light-yellow oil; yield: $63 \%$; $\mathrm{M}=192.25 \mathrm{~g} / \mathrm{mol}$; IR (ZnSe) $v=2937,1696,1682,1455,1346,1152,1138 \mathrm{~cm}^{-}$ ${ }^{1} ;{ }^{1} \mathrm{H}$ NMR $\left(300 \mathrm{MHz}, \mathrm{CDCl}_{3}\right) \delta$ 1.40-1.91 (m, 9H), 2.16-2.50 (m, 4H), 2.59-2.68 (m, 1H), 5.91-5.99 (m, 1H), 6.67-6.74 (m, $1 \mathrm{H}) ;{ }^{13} \mathrm{C}$ NMR $\left(75 \mathrm{MHz}, \mathrm{CDCl}_{3}\right) \delta 24.3\left(\mathrm{CH}_{2}\right), 26.5\left(\mathrm{CH}_{2}\right), 30.1\left(\mathrm{CH}_{2}\right), 31.6\left(\mathrm{CH}_{2}\right), 33.9\left(\mathrm{CH}_{2}\right), 36.4\left(\mathrm{CH}_{2}\right), 40.1\left(\mathrm{CH}_{2}\right)$, $53.3\left(\mathrm{C}_{\mathrm{q}}\right), 129.3(\mathrm{CH}), 150.9(\mathrm{CH}), 198.4\left(\mathrm{C}_{\mathrm{q}}\right), 212.3\left(\mathrm{C}_{\mathrm{q}}\right)$; HRMS: calcd. for $\mathrm{C}_{12} \mathrm{H}_{17} \mathrm{O}_{2} 193.12231$, found $193.12250(1.003$ ppm).

\subsubsection{1,4-dioxadispiro[4.0.5-6.5-5]hexadec-7-en-9-one (4)}

Under nitrogen atmosphere, to a solution of the spiro-derivative 3 ( $1 \mathrm{~g}, 1 \mathrm{eq}$.) in benzene were successively added ethylene glycol ( $3 \mathrm{ml}, 10$ eq.) and PTSA ( $0.05 \mathrm{~g}, 0.05$ eq.). The mixture was refluxed for $12 \mathrm{~h}$ with water distillation using a DeanStark trap. The solvent was removed under vacuum, the residue was dissolved in sodium bicarbonate (aq. satd. soln., $30 \mathrm{ml}$ ), then the organics extracted with DCM $(3 \times 30 \mathrm{ml})$. The combined organic layers were washed with brine $(100 \mathrm{ml})$, dried over magnesium sulfate and the solvent was evaporated under vacuum. The desired ketal was isolated by flashchromatography (PE/EtOAc 15/5) in mixture with an unidentified product (1/2 ratio as showed by H-NMR).

$\mathrm{C}_{14} \mathrm{H}_{20} \mathrm{O}_{3}$; light-yellow visc. oil; yield: $25 \% ; \mathrm{M}=236,14 \mathrm{~g} / \mathrm{mol}$; IR $(\mathrm{ZnSe}) v=2933,1682,1455,1225,1050 \mathrm{~cm}^{-1} ;{ }^{1} \mathrm{H}$ NMR $\left(300 \mathrm{MHz}, \mathrm{CDCl}_{3}\right) \delta 1.42-1.79(\mathrm{~m}, 10 \mathrm{H}), 1.84-1.98(\mathrm{~m}, 1 \mathrm{H}), 2.05-2.19(\mathrm{~m}, 1 \mathrm{H}), 2.26-2.52(\mathrm{~m}, 2 \mathrm{H}), 3.76-3.91(\mathrm{~m}$, $4 \mathrm{H}), 5.84(\mathrm{~d}, J=10.4 \mathrm{~Hz}, 1 \mathrm{H}), 6.83(\mathrm{dd}, J=10.4 \mathrm{~Hz}, J=1.4 \mathrm{~Hz}, 1 \mathrm{H}) ;{ }^{13} \mathrm{C}$ NMR $\left(75 \mathrm{MHz}, \mathrm{CDCl}_{3}\right) \delta 21.1\left(\mathrm{CH}_{2}\right), 22.5\left(\mathrm{CH}_{2}\right)$, $27.1\left(\mathrm{CH}_{2}\right), 27.6\left(\mathrm{CH}_{2}\right), 32.6\left(\mathrm{CH}_{2}\right), 33.3\left(\mathrm{CH}_{2}\right), 34.0\left(\mathrm{CH}_{2}\right), 46.8\left(\mathrm{C}_{\mathrm{q}}\right), 64.5\left(\mathrm{CH}_{2}\right), 64.7\left(\mathrm{CH}_{2}\right), 114.0\left(\mathrm{C}_{\mathrm{q}}\right), 127.5(\mathrm{CH})$, $155.5(\mathrm{CH}), 199.7\left(\mathrm{C}_{\mathrm{q}}\right)$; HRMS: calcd. for $\mathrm{C}_{14} \mathrm{H}_{21} \mathrm{O}_{3}$ 237.14852, found 237.14902 (2.104 ppm).

\subsubsection{9-oxo-1,4-dioxadispiro[4.0.5 $5^{6} .5^{5}$ hexadec-10-ene-8-carbaldehyde (5)}

Under inert atmosphere, the previously obtained ketal 4 (1.4 g, 1 eq.) was dissolved in dry toluene $(50 \mathrm{ml})$ and the mixture cooled to $-40^{\circ} \mathrm{C}$. Ethyl formate $(1.9 \mathrm{ml}, 4$ eq.) and then sodium hydride $(60 \%$ dispersion in oil, $0.94 \mathrm{~g}$, 4 eq.) were subsequently added before slowly adding methanol $(0.1 \mathrm{ml}, 0.5$ eq.) at low temperature over 15 minutes. The mixture was stirred for $30 \mathrm{~min}$ at low temperature, then left to slowly come back to room temperature and stirred for two additional hours. After the complete consumption of the starting material, the mixture was slowly poured onto ice-cold water $(100 \mathrm{ml})$, the organic layer was separated and washed two additional times with water $(2 \times 75 \mathrm{ml})$. The combined aqueous layers were subsequently acidified to with hydrogen chloride (aq. soln., $6 \mathrm{~N}$ ) before extracting the organic materials with diethyl ether (3 $\mathrm{x} 100 \mathrm{ml}$ ). The combined organic layers were dried over magnesium sulfate and the solvent evaporated to give a light yellow oil (turning brown on standing) and was subsequently used without further purification.

$\mathrm{C}_{15} \mathrm{H}_{20} \mathrm{O}_{4}$; Light yellow oil; Yield: $89 \%$; $\mathrm{M}=264.32 \mathrm{~g} / \mathrm{mol}$; IR (ZnSe) $v=2933,1641,1576,1444,1415,1192,1043 \mathrm{~cm}$

${ }^{1} ;{ }^{1} \mathrm{H}$ NMR $\left(300 \mathrm{MHz}, \mathrm{CDCl}_{3}\right) \delta 1.43-1.71(\mathrm{~m}, 8 \mathrm{H}), 1.75-1.85(\mathrm{~m}, 2 \mathrm{H}), 2.32(\mathrm{dd}, J=14.7 \mathrm{~Hz}, J=1.4 \mathrm{~Hz}, 1 \mathrm{H}), 2.68(\mathrm{dd}, J$ $=14.0 \mathrm{~Hz}, J=0.8 \mathrm{~Hz}, 1 \mathrm{H}), 3.87-3.99(\mathrm{~m}, 4 \mathrm{H}), 5.98(\mathrm{~d}, J=10.3 \mathrm{~Hz}, 1 \mathrm{H}), 6.79(\mathrm{dd}, J=10.3 \mathrm{~Hz}, J=1.7 \mathrm{~Hz}, 1 \mathrm{H}), 7.42(\mathrm{~s}$, $1 \mathrm{H}), 13.67(\mathrm{ls}, 1 \mathrm{H}) ;{ }^{13} \mathrm{C}$ NMR $\left(75 \mathrm{MHz}, \mathrm{CDCl}_{3}\right) \delta 21.2\left(\mathrm{CH}_{2}\right), 22.3\left(\mathrm{CH}_{2}\right), 27.5\left(\mathrm{CH}_{2}\right), 29.0\left(\mathrm{CH}_{2}\right), 32.6\left(\mathrm{CH}_{2}\right), 32.7\left(\mathrm{CH}_{2}\right)$, $48.3\left(\mathrm{C}_{\mathrm{q}}\right), 64.5\left(\mathrm{CH}_{2}\right), 64.9\left(\mathrm{CH}_{2}\right), 106.7\left(\mathrm{C}_{\mathrm{q}}\right), 113.6\left(\mathrm{C}_{\mathrm{q}}\right), 126.3(\mathrm{CH}), 153.7(\mathrm{CH}), 166.7(\mathrm{CH}), 189.4\left(\mathrm{C}_{\mathrm{q}}\right)$; HRMS: calcd. for $\mathrm{C}_{15} \mathrm{H}_{27} \mathrm{O}_{4} 265.14344$, found 265.14418 (2.807 ppm).

\subsubsection{1-(4-fluorophenyl)spiro[4H-indazole-5,2'-cycloheptane]-1'-one-ethylene-acetal (6)}

At room temperature, sodium acetate $(0.190 \mathrm{~g}, 1.2 \mathrm{eq}$.) and 4-F-phenylhydrazine $(0.37 \mathrm{~g}, 1.2 \mathrm{eq}$.) were added to a solution of the previously-obtained $\alpha$-formylation product $5(0.5 \mathrm{~g}, 1 \mathrm{eq}$.) in acetic acid $(10 \mathrm{ml})$. The mixture was stirred until the complete consumption of the starting material (approx. $1.5 \mathrm{~h}$ ), then the reaction was quenched by addition of sodium carbonate (sat. soln. $100 \mathrm{ml})$. The aqueous mixture was washed with ethyl acetate $(3 \times 100 \mathrm{ml})$, the combined organic layers were dried over magnesium sulfate and the solvent evaporated under reduced pressure. The crude product was subsequently purified by flash-chromatography (eluent: $\mathrm{PE} / \mathrm{EtOAc} 8 / 2$ ) to conduct to the desired indazole derivative 6.

$\mathrm{C}_{21} \mathrm{H}_{23} \mathrm{FN}_{2} \mathrm{O}_{2}$; light brown viscous oil; yield: $72 \%$; $\mathrm{M}=354.42 \mathrm{~g} / \mathrm{mol}$; IR $(\mathrm{ZnSe}) v=2922,1517,1225,1076 \mathrm{~cm}^{-1} ;{ }^{1} \mathrm{H}$ NMR $\left(300 \mathrm{MHz}, \mathrm{CDCl}_{3}\right) \delta 1.45-1.72(\mathrm{~m}, 8 \mathrm{H}), 1.82-1.87(\mathrm{~m}, 2 \mathrm{H}), 2.74(\mathrm{~d}, J=15.9 \mathrm{~Hz}, 1 \mathrm{H}), 2.92(\mathrm{~d}, J=15.9 \mathrm{~Hz}, 1 \mathrm{H}), 3.95-$ $4.02(\mathrm{~m}, 4 \mathrm{H}), 6.01(\mathrm{~d}, J=10.2 \mathrm{~Hz}, 1 \mathrm{H}), 6.39(\mathrm{~d}, J=10.2,1 \mathrm{H}), 7.11-7.16(\mathrm{~m}, 2 \mathrm{H}), 7.42-7.46(\mathrm{~m}, 2 \mathrm{H}) ;{ }^{13} \mathrm{C} \mathrm{NMR}(75 \mathrm{MHz}$, $\left.\mathrm{CDCl}_{3}\right)$ \& 21.1 $\left(\mathrm{CH}_{2}\right), 21.6\left(\mathrm{CH}_{2}\right), 25.7\left(\mathrm{CH}_{2}\right), 27.4\left(\mathrm{CH}_{2}\right), 32.0\left(\mathrm{CH}_{2}\right), 32.8\left(\mathrm{CH}_{2}\right), 49.0\left(\mathrm{C}_{q}\right), 64.6\left(\mathrm{CH}_{2}\right), 64.9\left(\mathrm{CH}_{2}\right), 113.6$ $(\mathrm{CH}), 114.3\left(\mathrm{C}_{\mathrm{q}}\right), 115.5\left(\mathrm{C}_{\mathrm{q}}\right), 116.0(\mathrm{CH}), 116.3(\mathrm{CH}), 125.2(\mathrm{CH}), 125.3(\mathrm{CH}), 136.6(\mathrm{CH}), 136.7\left(\mathrm{C}_{\mathrm{q}}\right), 138.7(\mathrm{CH}), 159.9$ $\left(\mathrm{C}_{\mathrm{q}}\right), 163.2\left(\mathrm{C}_{\mathrm{q}}\right)$; HRMS: calcd. for $\mathrm{C}_{21} \mathrm{H}_{24} \mathrm{FN}_{2} \mathrm{O}_{2}$ 355.18163, found 355.18277 (3.202 ppm). 
4.2.6 1-(4-fluorophenyl)spiro[4H-indazole-5,2'-cycloheptane]-1'-one (7c)

The ketal 6 was deprotected by adding hydrogen chloride (aq. soln. $6 \mathrm{~N}, 6 \mathrm{ml})$ to a solution of indazole $6(0.4 \mathrm{~g}, 1$ eq.) in THF $(12 \mathrm{ml})$. The reaction was conducted at $65^{\circ} \mathrm{C}$ for $1.5 \mathrm{~h}$, and then quenched by pouring onto a solution of sodium bicarbonate $(10 \%$ aq. soln. $100 \mathrm{ml})$. The aqueous solution was washed with ethyl acetate $(3 \times 100 \mathrm{ml})$, then the combined organic layers were dried over magnesium sulfate and the solvent evaporated under vacuum. The desired ketone $7 \mathbf{c}$ was isolated as a light yellow oil after purification on flash chromatography (eluent PE / EtOAc 8/2).

$\mathrm{C}_{19} \mathrm{H}_{19} \mathrm{FN}_{2} \mathrm{O}$; Light yellow visc. oil; Yield: $83 \%$; $\mathrm{M}=310.37 \mathrm{~g} / \mathrm{mol}$; $\mathrm{IR}(\mathrm{ZnSe}) v=2930,1703,1516,1222,841 \mathrm{~cm}^{-1}$; ${ }^{1} \mathrm{H}$ NMR $\left(300 \mathrm{MHz}, \mathrm{CDCl}_{3}\right) \delta 1.40-1.71(\mathrm{~m}, 6 \mathrm{H}), 1.80-1.84(\mathrm{~m}, 2 \mathrm{H}), 2.52-2.68(\mathrm{~m}, 3 \mathrm{H}), 3.23(\mathrm{~d}, J=16.1 \mathrm{~Hz}, 1 \mathrm{H}), 5.87(\mathrm{~d}$, $J=10.0 \mathrm{~Hz}, 1 \mathrm{H}), 6.45(\mathrm{dd}, J=10.0 \mathrm{~Hz}, J=0.5 \mathrm{~Hz}, 1 \mathrm{H}), 7.07-7.13(\mathrm{~m}, 2 \mathrm{H}), 7.37-7.43(\mathrm{~m}, 2 \mathrm{H}) ;{ }^{13} \mathrm{C} \mathrm{NMR}\left(75 \mathrm{MHz}, \mathrm{CDCl}_{3}\right)$

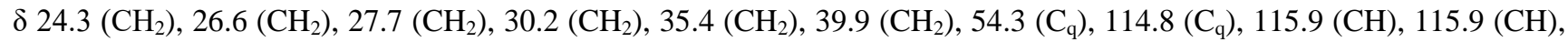
$116.2(\mathrm{CH}), 125.0(\mathrm{CH}), 125.2(\mathrm{CH}), 132.8(\mathrm{CH}), 135.6\left(\mathrm{C}_{\mathrm{q}}\right), 136.1\left(\mathrm{C}_{\mathrm{q}}\right), 138.1(\mathrm{CH}), 159.9\left(\mathrm{C}_{\mathrm{q}}\right), 163.1\left(\mathrm{C}_{\mathrm{q}}\right), 213.2\left(\mathrm{C}_{\mathrm{q}}\right)$; HRMS: calcd. for $\mathrm{C}_{13} \mathrm{H}_{20} \mathrm{FN}_{2} \mathrm{O} 311.15542$, found 311.15486 (-1.793 ppm).

\section{1-(4-fluorophenyl)-1'-phenyl-spiro[4H-indazole-5,2'-cyclohexane]-1'-ol}

Under inert atmosphere and at $0^{\circ} \mathrm{C}$, the previously obtained ketone $7 \mathbf{b}(0.3 \mathrm{~g}, 1$ eq.) was dissolved in dry THF $(10 \mathrm{ml})$. Phenylmagnesium bromide (1M soln. in THF, $1.02 \mathrm{ml}, 3$ eq.) was slowly added at low temperature and the mixture was stirred 2 additional hours at $0^{\circ} \mathrm{C}$ until the complete conversion of the starting material. The reaction was quenched by addition of ammonium chloride (satd. soln. $30 \mathrm{ml})$ and the organic-soluble materials extracted with ethyl acetate $(3 \times 50 \mathrm{ml})$. The organic phase was dried over magnesium sulfate and concentrated under vacuum. The solid residue was triturated with diethyl ether to give a white powder which was further crystallized in acetonitrile to conduct to the (5R, 8R)-diastereoisomer $(0.180 \mathrm{~g}, 48 \%)$, as confirmed by X-rays. The recovered filtrate was subsequently evaporated to conduct to a solid residue, further purified by flash-chromatography. The (5R, 8S)-diastereoisomer (as showed by crystallization in ethanol) was eluted first (PE/EtOAc 9/1, $0.103 \mathrm{~g}, 27 \%)$, then the remaining (5R, 8R)-diastereoisomer (0.031 g, 8\%).

\subsubsection{1-(4-fluorophenyl)-1'-phenyl-spiro[4H-indazole-5,2'-cyclohexane]-1'-ol (8b)}

(5R, 8R)-diastereoisomer: $\mathrm{C}_{24} \mathrm{H}_{23} \mathrm{FN}_{2} \mathrm{O}$; colourless crystals; $\mathrm{Mp}=234-236{ }^{\circ} \mathrm{C}$; Yield: $56 \%$; $\mathrm{M}=374.45 \mathrm{~g} / \mathrm{mol}$; IR (ZnSe) $v=2922,1513,837 \mathrm{~cm}^{-1} ;{ }^{1} \mathrm{H}$ NMR $(300 \mathrm{MHz}$, DMSO) $\delta 1.49-1.66(\mathrm{~m}, 5 \mathrm{H}), 1.79-1.88(\mathrm{~m}, 2 \mathrm{H}), 2.46(\mathrm{~d}, J=16.4 \mathrm{~Hz}, 1 \mathrm{H})$, $2.83(\mathrm{~d}, J=16.4 \mathrm{~Hz}, 1 \mathrm{H}), 4.85(\mathrm{~s}, 1 \mathrm{H}), 6.28(\mathrm{~d}, J=10.3 \mathrm{~Hz}, 1 \mathrm{H}), 6.46(\mathrm{~d}, J=10.4 \mathrm{~Hz}, 1 \mathrm{H}), 7.06(\mathrm{t}, J=7.2 \mathrm{~Hz}, 1 \mathrm{H}), 7.17(\mathrm{t}$, $J=7.5 \mathrm{~Hz}, 2 \mathrm{H}), 7.27-7.37(\mathrm{~m}, 5 \mathrm{H}), 7.50(\mathrm{~d}, J=7.4 \mathrm{~Hz}, 2 \mathrm{H})\left(1 \mathrm{H}\right.$ masked by the DMSO signal); ${ }^{13} \mathrm{C}$ NMR $(75 \mathrm{MHz}, \mathrm{DMSO})$ 反 $21.0\left(\mathrm{CH}_{2}\right), 21.4\left(\mathrm{CH}_{2}\right), 27.0\left(\mathrm{CH}_{2}\right), 34.0\left(\mathrm{CH}_{2}\right), 34.2\left(\mathrm{CH}_{2}\right), 44.4\left(\mathrm{C}_{\mathrm{q}}\right), 75.2\left(\mathrm{C}_{\mathrm{q}}\right), 114.5(\mathrm{CH}), 115.7\left(\mathrm{C}_{\mathrm{q}}\right), 115.9(\mathrm{CH})$, $116.2(\mathrm{CH}), 124.8(\mathrm{CH}), 124.9(\mathrm{CH}), 125.9(\mathrm{CH}), 126.6(2 \mathrm{CH}), 127.0(2 \mathrm{CH}), 135.3\left(\mathrm{C}_{\mathrm{q}}\right), 136.3(\mathrm{CH}), 137.8(\mathrm{CH}), 147.0$ $\left(\mathrm{C}_{\mathrm{q}}\right), 158.9\left(\mathrm{C}_{\mathrm{q}}\right), 162.2\left(\mathrm{C}_{\mathrm{q}}\right)$; MS: $m / z=375.2[\mathrm{M}+\mathrm{H}]^{+}$; HRMS: calcd. for $\mathrm{C}_{24} \mathrm{H}_{24} \mathrm{FN}_{2} \mathrm{O} 375.1867$, found $375.1863(-1.2371$ $\mathrm{ppm})$.

\subsubsection{1-(4-fluorophenyl)-1'-phenyl-spiro[4H-indazole-5,2'-cyclohexane]-1'-ol (9b)}

(5R, 8S)-diastereoisomer: $\mathrm{C}_{24} \mathrm{H}_{23} \mathrm{FN}_{2} \mathrm{O}$; colourless crystals; $\mathrm{Mp}=173-175^{\circ} \mathrm{C}$; Yield: $27 \%$; $\mathrm{M}=374.45 \mathrm{~g} / \mathrm{mol}$; IR (ZnSe) $v=3369,2936,1513,1265, \mathrm{~cm}^{-1} ;{ }^{1} \mathrm{H}$ NMR $\left(300 \mathrm{MHz}, \mathrm{CDCl}_{3}\right) \delta 1.56-1.77(\mathrm{~m}, 5 \mathrm{H}), 1.86-1.97(\mathrm{~m}, 2 \mathrm{H}), 2.56(\mathrm{dd}, J=4.1$ $\mathrm{Hz}, J=9.5 \mathrm{~Hz}, 1 \mathrm{H}), 2.64(\mathrm{~d}, J=15.9 \mathrm{~Hz}, 1 \mathrm{H}), 2.90(\mathrm{~d}, J=15.9 \mathrm{~Hz}, 1 \mathrm{H}), 6.25(\mathrm{~d}, J=10.2 \mathrm{~Hz}, 1 \mathrm{H}), 6.41(\mathrm{~d}, J=10.3 \mathrm{~Hz}$, $1 \mathrm{H}), 7.07-7.18(\mathrm{~m}, 3 \mathrm{H}), 7.23-7.33(\mathrm{~m}, 5 \mathrm{H}), 7.46-7.49(\mathrm{~m}, 2 \mathrm{H}) ;{ }^{13} \mathrm{C}$ NMR $\left(75 \mathrm{MHz}, \mathrm{CDCl}_{3}\right) \delta 20.1(\mathrm{CH} 2), 21.0\left(\mathrm{CH}_{2}\right)$, $25.1\left(\mathrm{CH}_{2}\right), 30.3\left(\mathrm{CH}_{2}\right), 33.7\left(\mathrm{CH}_{2}\right), 45.5\left(\mathrm{C}_{\mathrm{q}}\right), 76.7\left(\mathrm{C}_{\mathrm{q}}\right), 114.3(\mathrm{CH}), 115.0\left(\mathrm{C}_{\mathrm{q}}\right), 115.9(\mathrm{CH}), 116.2(\mathrm{CH}), 125.1(\mathrm{CH}), 125.2$ $(\mathrm{CH}), 127.1(\mathrm{CH}), 127.1(2 \mathrm{CH}), 127.5(2 \mathrm{CH}), 136.4\left(\mathrm{C}_{\mathrm{q}}\right), 137.9(\mathrm{CH}), 146.3\left(\mathrm{C}_{\mathrm{q}}\right), 159.9\left(\mathrm{C}_{\mathrm{q}}\right), 163.2\left(\mathrm{C}_{\mathrm{q}}\right) ; \mathrm{MS}: \mathrm{m} / \mathrm{z}=375.2$ $[\mathrm{M}+\mathrm{H}]^{+}$; HRMS: calcd. for $\mathrm{C}_{24} \mathrm{H}_{24} \mathrm{FN}_{2} \mathrm{O} 375.18672$, found 375.18586 (-2.287 ppm).

\section{1-(4-fluorophenyl)-1'-phenyl-spiro[4H-indazole-5,2'-cycloheptane]-1'-ol}

Phenylmagnesium bromide (1M in THF, $0.97 \mathrm{ml}, 0.97 \mathrm{mmol}, 3$ eq.) was slowly added at $0^{\circ} \mathrm{C}$ to a solution of ketone $7 \mathbf{b}(0.1$ g, $0.32 \mathrm{mmol}, 1$ eq.) in dry THF $(10 \mathrm{ml})$. After $2 \mathrm{~h}$ at low temperature, the reaction was quenched by addition of water (20 $\mathrm{ml})$, and the organics extracted with ethyl acetate $(3 \times 20 \mathrm{ml})$. The recovered organic layers were dried over magnesium sulfate, concentrated under vacuum and further purified by flash chromatography (PE / EtOAc 9/1). The (5R, 8S)diastereoisomer was eluted firstly $(38 \%)$, then the $(5 \mathrm{R}, 8 \mathrm{R})$-diastereoisomer $(10 \%)$, followed by the recovered starting material (20\%).

\subsubsection{1-(4-fluorophenyl)-1'-phenyl-spiro[4H-indazole-5,2'-cycloheptane]-1'-ol (8d)}

(5R, 8R)-diastereoisomer: $\mathrm{C}_{25} \mathrm{H}_{25} \mathrm{FN}_{2} \mathrm{O}$; White solid; $\mathrm{Mp}=130-131{ }^{\circ} \mathrm{C}$; Yield: $10 \% ; \mathrm{M}=388.48 \mathrm{~g} / \mathrm{mol}$; IR (ZnSe) $v=$ $3333,2923,1515,1222,839 \mathrm{~cm}^{-1}$; ${ }^{1} \mathrm{H}$ NMR $\left(300 \mathrm{MHz}, \mathrm{CDCl}_{3}\right) \delta 1.52-1.73(\mathrm{~m}, 6 \mathrm{H}), 1.85-2.11(\mathrm{~m}, 4 \mathrm{H}), 2.49-2.59(\mathrm{~m}, 1 \mathrm{H})$, $2.64(\mathrm{~d}, J=16.1 \mathrm{~Hz}, 1 \mathrm{H}), 2.81(\mathrm{~d}, J=16.1 \mathrm{~Hz}, 1 \mathrm{H}), 6.15(\mathrm{dd}, J=10.4 \mathrm{~Hz}, 1 \mathrm{H}), 6.34(\mathrm{dd}, J=10.3 \mathrm{~Hz}, J=0.5 \mathrm{~Hz}, 1 \mathrm{H})$, 7.08-7.17 (m, 3H), 7.23-7.28 (m, 3H), 7.34-7.38 (m, 2H), 7.46-7.49 (m, 2H); ${ }^{13} \mathrm{C}$ NMR (75 MHz, $\left.\mathrm{CDCl}_{3}\right) \delta 20.8\left(\mathrm{CH}_{2}\right), 21.9$ 
$\left(\mathrm{CH}_{2}\right), 27.0\left(\mathrm{CH}_{2}\right), 28.8\left(\mathrm{CH}_{2}\right), 30.8\left(\mathrm{CH}_{2}\right), 41.6\left(\mathrm{CH}_{2}\right), 49.2\left(\mathrm{C}_{\mathrm{q}}\right), 79.8\left(\mathrm{C}_{\mathrm{q}}\right), 115.0(\mathrm{CH}), 116.0(\mathrm{CH}), 116.3(\mathrm{CH}), 116.5$ $\left(\mathrm{C}_{\mathrm{q}}\right), 125.1(\mathrm{CH}), 125.2(\mathrm{CH}), 126.6(\mathrm{CH}), 126.7(2 \mathrm{CH}), 127.7(2 \mathrm{CH}), 135.4(\mathrm{CH}), 136.1\left(\mathrm{C}_{\mathrm{q}}\right), 138.6(\mathrm{CH}), 148.4\left(\mathrm{C}_{\mathrm{q}}\right), 163.2$ $\left(\mathrm{C}_{\mathrm{q}}\right) ; \mathrm{MS} \mathrm{m} / \mathrm{z}=389.2[\mathrm{M}+\mathrm{H}]^{+}$; HRMS: calcd. for $\mathrm{C}_{25} \mathrm{H}_{28} \mathrm{FN}_{2} \mathrm{O} 389.20285$, found 389.20136 (-2.590 ppm).

4.2.10 1-(4-fluorophenyl)-1'-phenyl-spiro[4H-indazole-5,2'-cycloheptane]-1'-ol (9d)

(5R, 8S)-diastereoisomer: $\mathrm{C}_{25} \mathrm{H}_{25} \mathrm{FN}_{2} \mathrm{O}$; White solid; $\mathrm{Mp}=145-147{ }^{\circ} \mathrm{C}$; Yield: $38 \%$; $\mathrm{M}=388.48 \mathrm{~g} / \mathrm{mol} ; \mathrm{IR}(\mathrm{ZnSe})$ $v=3331,2922,1521,1229,846 \mathrm{~cm}^{-1}$; ${ }^{1} \mathrm{H}$ NMR $\left(300 \mathrm{MHz}, \mathrm{CDCl}_{3}\right) \delta 1.50-2.04(\mathrm{~m}, 9 \mathrm{H}), 2.12-2.22(\mathrm{~m}, 1 \mathrm{H}), 2.55-2.65$ $(\mathrm{m}, 1 \mathrm{H}), 2.82(\mathrm{q}, J=15.9 \mathrm{~Hz}, 2 \mathrm{H}), 6.14(\mathrm{dd}, J=10.3 \mathrm{~Hz}, J=0.6 \mathrm{~Hz}, 1 \mathrm{H}), 6.31(\mathrm{~d}, J=10.3 \mathrm{~Hz}, 1 \mathrm{H}), 7.06-7.21(\mathrm{~m}$, $6 \mathrm{H}), 7.25-7.30(\mathrm{~m}, 2 \mathrm{H}), 7.44-7.47(\mathrm{~m}, 2 \mathrm{H}) ;{ }^{13} \mathrm{C} \mathrm{NMR}\left(75 \mathrm{MHz}, \mathrm{CDCl}_{3}\right) \delta 20.7\left(\mathrm{CH}_{2}\right), 22.0\left(\mathrm{CH}_{2}\right), 26.1\left(\mathrm{CH}_{2}\right), 27.1$ $\left(\mathrm{CH}_{2}\right), 33.4\left(\mathrm{CH}_{2}\right), 38.9\left(\mathrm{CH}_{2}\right), 48.3\left(\mathrm{C}_{\mathrm{q}}\right), 79.4\left(\mathrm{C}_{\mathrm{q}}\right), 113.2(\mathrm{CH}), 115.4\left(\mathrm{C}_{\mathrm{q}}\right), 115.9(\mathrm{CH}), 116.2(\mathrm{CH}), 125.1(\mathrm{CH})$, $125.2(\mathrm{CH}), 126.9(\mathrm{CH}), 127.0(\mathrm{CH}), 127.2(\mathrm{CH}), 136.5\left(\mathrm{C}_{\mathrm{q}}\right), 137.8(\mathrm{CH}), 138.9(\mathrm{CH}), 148.0\left(\mathrm{C}_{\mathrm{q}}\right), 159.9\left(\mathrm{C}_{\mathrm{q}}\right), 163.1$ $\left(\mathrm{C}_{\mathrm{q}}\right)$; HRMS: calcd. for $\mathrm{C}_{25} \mathrm{H}_{28} \mathrm{FN}_{2} \mathrm{O} 389.20237$, found 389.20341 (2.677 ppm).

\section{1'-benzyl-1-(4-fluorophenyl)spiro[4H-indazole-5,2'-cycloheptane]-1'-ol}

The title compound was obtained following the same experimental method employed for the synthesis of compound 8d-9d, after $2 \mathrm{~h}$ of reaction at $0^{\circ} \mathrm{C}$. Purification by flash-chromatography (eluent: 9/1 PE/EtOAc) delivered the (5R, $8 \mathrm{R})$-diastereoisomer followed by the (5R, 8S)-diastereoisomer. The secondly eluted diastereoisomer was crystallized in ACN and submitted to X- Rays diffractions in order to confirm the proposed stereochemistry.

\subsubsection{1'-benzyl-1-(4-fluorophenyl)spiro[4H-indazole-5,2'-cycloheptane]-1'-ol (8e)}

(5R, 8S)-diastereoisomer: $\mathrm{C}_{25} \mathrm{H}_{25} \mathrm{FN}_{2} \mathrm{O}$; White solid; $\mathrm{Mp}=144-146{ }^{\circ} \mathrm{C}$; Yield: $20 \% ; \mathrm{M}=402.50 \mathrm{~g} / \mathrm{mol}$; IR (ZnSe) $v=3574,2926,1515,1222,1079,839 \mathrm{~cm}^{-1} ;{ }^{1} \mathrm{H}$ NMR $\left(300 \mathrm{MHz}, \mathrm{CDCl}_{3}\right) \delta 1.41-1.87(\mathrm{~m}, 10 \mathrm{H}), 2.52(\mathrm{~d}, J=13.5$ $\mathrm{Hz}, 1 \mathrm{H}), 2.75(\mathrm{~d}, J=16.6 \mathrm{~Hz}, 1 \mathrm{H}), 3.12(\mathrm{~d}, J=13.5 \mathrm{~Hz}, 1 \mathrm{H}), 3.28(\mathrm{~d}, J=16.6 \mathrm{~Hz}, 1 \mathrm{H}), 5.93(\mathrm{~d}, J=10.3 \mathrm{~Hz}, 1 \mathrm{H})$, $6.47(\mathrm{~d}, J=10.3 \mathrm{~Hz}, 1 \mathrm{H}), 7.14-7.35(\mathrm{~m}, 7 \mathrm{H}), 7.45-7.50(\mathrm{~m}, 3 \mathrm{H}) ;{ }^{13} \mathrm{C} \mathrm{NMR}\left(75 \mathrm{MHz}, \mathrm{CDCl}_{3}\right) \delta 20.0\left(\mathrm{CH}_{2}\right), 21.1$ $\left(\mathrm{CH}_{2}\right), 27.0\left(\mathrm{CH}_{2}\right), 27.7\left(\mathrm{CH}_{2}\right), 31.4\left(\mathrm{CH}_{2}\right), 35.7\left(\mathrm{CH}_{2}\right), 45.6\left(\mathrm{CH}_{2}\right), 48.6\left(\mathrm{C}_{\mathrm{q}}\right), 63.5(\mathrm{CH} 2) 77.0\left(\mathrm{C}_{\mathrm{q}}\right), 114.6(\mathrm{CH}), 116.1$ $(\mathrm{CH}), 116.4(\mathrm{CH}), 125.3(\mathrm{CH}), 125.4(\mathrm{CH}), 126.7(\mathrm{CH}), 128.5(2 \mathrm{CH}), 131.4(2 \mathrm{CH}), 135.6(\mathrm{CH}), 137.4\left(\mathrm{C}_{\mathrm{q}}\right), 139.0$ $(\mathrm{CH}) ; \mathrm{MS} \mathrm{m} / \mathrm{z}=403.2[\mathrm{M}+\mathrm{H}]^{+}$; HRMS: calcd. for $\mathrm{C}_{26} \mathrm{H}_{28} \mathrm{FN}_{2} \mathrm{O} 403.21855$, found 403.21711 (-2.252 ppm).

\subsubsection{1'-benzyl-1-(4-fluorophenyl)spiro[4H-indazole-5,2'-cycloheptane]-1'-ol (9e)}

(5R, 8R)-diastereoisomer: $\mathrm{C}_{25} \mathrm{H}_{25} \mathrm{FN}_{2} \mathrm{O}$; White solid; $\mathrm{Mp}=127-129^{\circ} \mathrm{C}$; Yield: $18 \%$; $\mathrm{M}=402.50 \mathrm{~g} / \mathrm{mol}$; IR $(\mathrm{ZnSe}) \mathrm{v}=$ 3390, 2926, 1514, 1225, 1079, $838 \mathrm{~cm}^{-1} ;{ }_{1}^{1} \mathrm{H}$ NMR (300 MHz, $\left.\mathrm{CDCl}_{3}\right) \delta 1.48-1.71(\mathrm{~m}, 9 \mathrm{H}), 2.02-2.11(\mathrm{~m}, 1 \mathrm{H}), 2.73-3.02$ $(\mathrm{m}, 4 \mathrm{H}), 6.36(\mathrm{~d}, J=10.3 \mathrm{~Hz}, 1 \mathrm{H}), 6.47(\mathrm{~d}, J=10.3 \mathrm{~Hz}, 1 \mathrm{H}), 7.13-7.35(\mathrm{~m}, 7 \mathrm{H}), 7.45-7.50(\mathrm{~m}, 3 \mathrm{H}) ;{ }^{13} \mathrm{C} \mathrm{NMR}(75 \mathrm{MHz}$, $\left.\mathrm{CDCl}_{3}\right) \delta 21.0\left(\mathrm{CH}_{2}\right), 22.5\left(\mathrm{CH}_{2}\right), 25.5\left(\mathrm{CH}_{2}\right), 26.5\left(\mathrm{CH}_{2}\right), 31.1\left(\mathrm{CH}_{2}\right), 35.9\left(\mathrm{CH}_{2}\right), 44.7\left(\mathrm{CH}_{2}\right), 48.8\left(\mathrm{C}_{\mathrm{q}}\right), 77.3\left(\mathrm{C}_{\mathrm{q}}\right), 113.7$ $(\mathrm{CH}), 115.2\left(\mathrm{C}_{\mathrm{q}}\right), 116.1(\mathrm{CH}), 116.4(\mathrm{CH}), 125.2(\mathrm{CH}), 125.3(\mathrm{CH}), 126.8(\mathrm{CH}), 128.5(2 \mathrm{CH}), 131.5(2 \mathrm{CH}), 136.9\left(\mathrm{C}_{\mathrm{q}}\right)$, $137.5\left(\mathrm{C}_{\mathrm{q}}\right), 138.4(\mathrm{CH}), 138.7(\mathrm{CH}), 160.0\left(\mathrm{C}_{\mathrm{q}}\right), 163.3\left(\mathrm{C}_{\mathrm{q}}\right)$; HRMS: calcd. for $\mathrm{C}_{26} \mathrm{H}_{28} \mathrm{FN}_{2} \mathrm{O} 403.2180$, found 403.21873 (1.765 ppm).

\subsubsection{1'-(4-fluorophenyl)-2-phenyl-1',4'-dihydrospiro-[cyclohex-2-ene-1,5'-indazole] (10a)}

Dry toluene $(10 \mathrm{ml})$ was added to a crude mixture of diasteroisomers $\mathbf{8 b - 9 b}$ (obtained from $0.5 \mathrm{~g}$ of ketone $\mathbf{7 b}$ as described above). Triflic anhydride ( $0.7 \mathrm{ml}, 4.2 \mathrm{mmol}, 2.5 \mathrm{eq}$.) was subsequently added to the solution and the mixture was heated at $100^{\circ} \mathrm{C}$ under stirring for $10 \mathrm{~min}$. After cooling to room temperature, the mixture was diluted with ethyl acetate (25 ml) and poured onto sodium bicarbonate (satd. soln., $30 \mathrm{ml}$ ). Theo organic materials were extracted with ethyl acetate $(3 \mathrm{x} 50 \mathrm{ml})$, dried over magnesium sulfate and concentrated under vacuum. The crude product was purified by flash chromatography (PE / EtOAc 95 / 5) to conduct to the desired elimination product (15\%) along with an unidentified product.

$\mathrm{C}_{24} \mathrm{H}_{21} \mathrm{FN}_{2}$; light yellow oil; Yield: $15 \%$; $=356.43 \mathrm{~g} / \mathrm{mol}$; IR $(\mathrm{ZnSe}) v=2932,1515,1224 \mathrm{~cm}^{-1} ;{ }^{1} \mathrm{H} \mathrm{NMR}(300 \mathrm{MHz}$, $\left.\mathrm{CDCl}_{3}\right) \delta 1.60-1.70(\mathrm{~m}, 3 \mathrm{H}), 1.80-1.88(\mathrm{~m}, 1 \mathrm{H}), 2.12-2.22(\mathrm{~m}, 2 \mathrm{H}), 2.49(\mathrm{~d}, J=16.3 \mathrm{~Hz}, 1 \mathrm{H}), 2.97(\mathrm{~d}, J=16.3 \mathrm{~Hz}, 1 \mathrm{H})$, $5.85(\mathrm{t}, J=3.9 \mathrm{~Hz}, 1 \mathrm{H}), 6.02(\mathrm{~d}, J=10.0 \mathrm{~Hz}, 1 \mathrm{H}), 6.32(\mathrm{~d}, J=10.0 \mathrm{~Hz}, 1 \mathrm{H}), 7.03-7.24(\mathrm{~m}, 8 \mathrm{H}), 7.30-7.36(\mathrm{~m}, 2 \mathrm{H}) ;{ }^{13} \mathrm{C}$ NMR (75 MHz, $\left.\mathrm{CDCl}_{3}\right) \delta 18.3\left(\mathrm{CH}_{2}\right), 26.2\left(\mathrm{CH}_{2}\right), 30.8\left(\mathrm{CH}_{2}\right), 36.1\left(\mathrm{CH}_{2}\right), 41.0\left(\mathrm{C}_{\mathrm{q}}\right), 113.8(\mathrm{CH}), 115.4\left(\mathrm{C}_{\mathrm{q}}\right), 116.0(\mathrm{CH})$, $116.3(\mathrm{CH}), 125.3(\mathrm{CH}), 125.4(\mathrm{CH}), 126.4(\mathrm{CH}), 127.8(2 \mathrm{CH}), 128.8(\mathrm{CH}), 128.8(2 \mathrm{CH}), 136.1\left(\mathrm{C}_{\mathrm{q}}\right), 138.3(\mathrm{CH}), 140.8$ $(\mathrm{CH}), 142.7\left(\mathrm{C}_{\mathrm{q}}\right), 144.0\left(\mathrm{C}_{\mathrm{q}}\right), 160.0\left(\mathrm{C}_{\mathrm{q}}\right), 163.2\left(\mathrm{C}_{\mathrm{q}}\right)$; HRMS: calcd. for $\mathrm{C}_{24} \mathrm{H}_{22} \mathrm{FN}_{2} 357.17615$, found $357.17532(-2.333$ ppm).

\subsubsection{4-[1-(4-fluorophenyl)spiro[4H-indazole-5,6'-cyclohexene]-1'-yl]phenol (10b)}

Under inert atmosphere, (4-bromophenoxy)-triisopropylsilane (0.56 g, $1.69 \mathrm{mmol}, 2 \mathrm{eq}$.$) was dissolved in dry THF (15 ml)$ and the mixture cooled at $-78^{\circ} \mathrm{C}$ before slowly adding a solution of $n$-butyl lithium $(1.5 \mathrm{M}$ in THF, $1.25 \mathrm{ml}, 1.85 \mathrm{mmol}, 2.2$ eq.). After $30 \mathrm{~min}$ of stirring at $-78^{\circ} \mathrm{C}$, a solution of the ketone $7 \mathbf{b}(0.25 \mathrm{~g}, 0.84 \mathrm{mmol}, 1 \mathrm{eq}$.) in dry THF (5 ml) was added and the mixture was allowed to slowly come back to room temperature overnight. The reaction was quenched by addition 
of water $(100 \mathrm{ml})$ and the organic materials were extracted with ethyl acetate $(3 \times 100 \mathrm{ml})$ before removing the solvent under vacuum. The crude product was purified by flash-chromatography (PE / EtOAc 9/1 to 8/2) to deliver the desired addition product. Starting material was also recovered during the purification (30\%).

$\mathrm{C}_{33} \mathrm{H}_{43} \mathrm{FN}_{2} \mathrm{O}_{2} \mathrm{Si}$; Colorless vis. oil; Yield: $57 \%$; $\mathrm{M}=546.79 \mathrm{~g} / \mathrm{mol}$; IR (ZnSe) $v=3380,2948,1601,1517,1269,835 \mathrm{~cm}^{-}$

' ${ }^{1}{ }^{1} \mathrm{H}$ NMR $\left(300 \mathrm{MHz}, \mathrm{CDCl}_{3}\right) \delta 1.04(\mathrm{~d}, J=6.8 \mathrm{~Hz}, 18 \mathrm{H}), 1.12-1.29(\mathrm{~m}, 3 \mathrm{H}), 1.6-1.83(\mathrm{~m}, 8 \mathrm{H}), 2.41-2.52(\mathrm{~m}, 1 \mathrm{H}), 2.51$ $(\mathrm{d}, J=16.3 \mathrm{~Hz}, 1 \mathrm{H}), 3.10(\mathrm{~d}, J=16.3 \mathrm{~Hz}, 1 \mathrm{H}), 6.24(\mathrm{q}, J=10.3 \mathrm{~Hz}, 2 \mathrm{H}), 6.69(\mathrm{~d}, J=8.7 \mathrm{~Hz}, 2 \mathrm{H}), 7.09(\mathrm{t}, J=8.6 \mathrm{~Hz}, 2 \mathrm{H})$, 7.22 (s, 1H), 7.27-7.32 (m, 4H); ${ }^{13} \mathrm{C}$ NMR $\left(75 \mathrm{MHz}, \mathrm{CDCl}_{3}\right) \delta 12.7(3 \mathrm{CH}), 18.0\left(6 \mathrm{CH}_{3}\right), 21.5\left(\mathrm{CH}_{2}\right), 21.8\left(\mathrm{CH}_{2}\right), 27.6\left(\mathrm{CH}_{2}\right)$, $34.9\left(\mathrm{CH}_{2}\right), 35.8\left(\mathrm{CH}_{2}\right), 44.9\left(\mathrm{C}_{\mathrm{q}}\right), 76.6\left(\mathrm{C}_{\mathrm{q}}\right), 115.5(\mathrm{CH}), 115.8(\mathrm{CH}), 116.1(\mathrm{CH}), 116.5\left(\mathrm{C}_{\mathrm{q}}\right), 118.5(2 \mathrm{CH}), 125.1(\mathrm{CH})$, 125.2 $(\mathrm{CH}), 127.8(2 \mathrm{CH}), 135.2(\mathrm{CH}), 135.9\left(\mathrm{C}_{\mathrm{q}}\right), 138.0(\mathrm{CH}), 138.3\left(\mathrm{C}_{\mathrm{q}}\right), 154.8\left(\mathrm{C}_{\mathrm{q}}\right), 159.9\left(\mathrm{C}_{\mathrm{q}}\right), 163.1\left(\mathrm{C}_{\mathrm{q}}\right)$; HRMS: calcd. for $\mathrm{C}_{33} \mathrm{H}_{44} \mathrm{FN}_{2} \mathrm{O}_{2} \mathrm{Si}$ 547.31506, found 547.31572 (1.206 ppm).

The previously obtained alcohol ( $0.09 \mathrm{~g}, 0.0 .164 \mathrm{mmol}, 1 \mathrm{eq}$.) was dissolved in THF ( $3 \mathrm{ml})$ and the solution was cooled to $0^{\circ} \mathrm{C}$ in an ice-bath before slowly adding a solution of TBAF (1M in DCM, $0.5 \mathrm{ml}, 0.5 \mathrm{mmol}, 3$ eq.). After $5 \mathrm{~min}$ the TLC indicated the complete consumption of the starting material. The reaction was quenched by addition of sodium bicarbonate (20\% aq. soln. $20 \mathrm{ml})$ and the organics extracted by EtOAc $(3 \times 20 \mathrm{ml})$. The combined organic layers were dried over magnesium sulphate and further concentrated under vacuum to deliver a crude product. This was subsequently purified by flash-chromatography (DCM / MeOH 9/1), to conduct to the desired deprotected phenol. The isolated fraction was further triturated in diethyl ether to deliver a white powder, subsequently filtered on a glass-sintered funnel and dried under vacuum. $\mathrm{C}_{24} \mathrm{H}_{23} \mathrm{FN}_{2} \mathrm{O}_{2}$; White solid; $\mathrm{Mp}=182-184^{\circ} \mathrm{C}$; Yield: $76 \%$; $\mathrm{M}=390.45 \mathrm{~g} / \mathrm{mol}$; IR (ZnSe) $v=3401,2973,1663,1612$, 1517, 1229, $1021 \mathrm{~cm}^{-1}$; ${ }^{1} \mathrm{H}$ NMR (300 MHz, $\left.\mathrm{CDCl}_{3}\right) \delta 1.54-1.91(\mathrm{~m}, 8 \mathrm{H}), 2.38-2.44(\mathrm{~m}, 2 \mathrm{H}), 3.29(\mathrm{t}, J=16.5 \mathrm{~Hz}, 1 \mathrm{H})$, $6.19(\mathrm{~s}, 2 \mathrm{H}), 6.53(\mathrm{~d}, J=8.7 \mathrm{~Hz}, 2 \mathrm{H}), 7.03(\mathrm{t}, J=8.6 \mathrm{~Hz}, 2 \mathrm{H}), 7.15-7.31(\mathrm{~m}, 6 \mathrm{H}) ;{ }^{13} \mathrm{C} \mathrm{NMR}\left(75 \mathrm{MHz}, \mathrm{CDCl}_{3}\right) \delta 21.3\left(\mathrm{CH}_{2}\right)$, 21.6 $\left(\mathrm{CH}_{2}\right), 27.7\left(\mathrm{CH}_{2}\right), 35.1\left(\mathrm{CH}_{2}\right), 35.6\left(\mathrm{CH}_{2}\right), 44.6\left(\mathrm{C}_{\mathrm{q}}\right), 76.3\left(\mathrm{C}_{\mathrm{q}}\right), 113.5(2 \mathrm{CH}), 115.9(\mathrm{CH}), 116.2(\mathrm{CH}), 116.3(\mathrm{CH})$, 117.1 $\left(\mathrm{C}_{\mathrm{q}}\right), 125.6(\mathrm{CH}), 125.7(\mathrm{CH}), 128.0(2 \mathrm{CH}), 134.7(\mathrm{CH}), 136.6\left(\mathrm{C}_{\mathrm{q}}\right), 136.8\left(\mathrm{C}_{\mathrm{q}}\right), 137.2(\mathrm{CH}), 155.3\left(\mathrm{C}_{\mathrm{q}}\right), 160.1\left(\mathrm{C}_{\mathrm{q}}\right)$, $163.4\left(\mathrm{C}_{\mathrm{q}}\right)$; HRMS: calcd. for $\mathrm{C}_{24} \mathrm{H}_{24} \mathrm{FN}_{2} \mathrm{O}_{2} 391.18163$, found 391.18276 (2.882 ppm).

The previously obtained phenol ( $0.1 \mathrm{~g}, 0.25 \mathrm{mmol}, 1 \mathrm{eq}$.) was dissolved in dry DCM ( $2 \mathrm{ml})$ then the mixture was cooled to $78^{\circ} \mathrm{C}$ before slowly adding boron tribromide ( $1 \mathrm{M}$ in DCM, $0.3 \mathrm{ml}, 0.3 \mathrm{mmol}, 1.2 \mathrm{eq}$.). The reaction was continued at low temperature for $1 \mathrm{~h}$, and then quenched with sodium bicarbonate ( $20 \%$ aq. soln., $10 \mathrm{ml}$ ). The organic materials were extracted with DCM $(3 \times 10 \mathrm{ml})$, the combined organic layers were dried over magnesium sulfate and the crude product purified by flash-chromatography (PE / EtOAc 15/5) to deliver the dehydrated product 10b.

$\mathrm{C}_{24} \mathrm{H}_{21} \mathrm{FN} 2 \mathrm{O}$; White solid; $\mathrm{Mp}=77-79^{\circ} \mathrm{C}$; Yield: $83 \%$; $\mathrm{M}=372.43 \mathrm{~g} / \mathrm{mol}$; IR $(\mathrm{ZnSe}) v=3320,2933,1609,1517,1265$, $1229 \mathrm{~cm}^{-1} ;{ }^{1} \mathrm{H}$ NMR $\left(300 \mathrm{MHz}, \mathrm{CDCl}_{3}\right) \delta 1.68-1.91(\mathrm{~m}, 4 \mathrm{H}), 2.20-2.24(\mathrm{~m}, 2 \mathrm{H}), 2.57(\mathrm{~d}, J=16.3 \mathrm{~Hz}, 1 \mathrm{H}), 3.05(\mathrm{~d}, J=16.3$ $\mathrm{Hz}, 1 \mathrm{H}), 5.85(\mathrm{t}, J=3.9 \mathrm{~Hz}, 1 \mathrm{H}), 6.04(\mathrm{~d}, J=10.0 \mathrm{~Hz}, 1 \mathrm{H}), 6.35(\mathrm{dd}, J=10.0 \mathrm{~Hz}, J=0.5 \mathrm{~Hz}, 1 \mathrm{H}), 6.62-6.65(\mathrm{~m}, 2 \mathrm{H}), 6.83$ $(\mathrm{s}, 1 \mathrm{H}), 7.07-7.14(\mathrm{~m}, 4 \mathrm{H}), 7.33(\mathrm{~s}, 1 \mathrm{H}), 7.36-7.41(\mathrm{~m}, 2 \mathrm{H}) ;{ }^{13} \mathrm{C}$ NMR $\left(75 \mathrm{MHz}, \mathrm{CDCl}_{3}\right) \delta 18.3\left(\mathrm{CH}_{2}\right), 26.1\left(\mathrm{CH}_{2}\right), 30.7$ $\left(\mathrm{CH}_{2}\right), 36.0\left(\mathrm{CH}_{2}\right), 41.0\left(\mathrm{C}_{\mathrm{q}}\right), 113.6(\mathrm{CH}), 114.7(2 \mathrm{CH}), 115.5\left(\mathrm{C}_{\mathrm{q}}\right), 116.1(\mathrm{CH}), 116.4(\mathrm{CH}), 125.5(\mathrm{CH}), 125.6(\mathrm{CH}), 127.7$ $(\mathrm{CH}), 129.9(2 \mathrm{CH}), 134.7\left(\mathrm{C}_{\mathrm{q}}\right), 136.5\left(\mathrm{C}_{\mathrm{q}}\right), 138.3(\mathrm{CH}), 141.3(\mathrm{CH}), 143.3\left(\mathrm{C}_{\mathrm{q}}\right), 154.9\left(\mathrm{C}_{\mathrm{q}}\right), 160.1\left(\mathrm{C}_{\mathrm{q}}\right), 163.4\left(\mathrm{C}_{\mathrm{q}}\right)$; HRMS: calcd. for $\mathrm{C}_{24} \mathrm{H}_{22} \mathrm{FN}_{2} \mathrm{O} 373.171068$, found 373.16948 ( $\left.-4.26 \mathrm{ppm}\right)$.

\subsubsection{1-(4-fluorophenyl)-1'-(4-methoxyphenyl)spiro[4H-indazole-5,6'-cyclohexene] (10c)}

Under inert atmosphere, $\mathrm{iPrMgCl}\left(2 \mathrm{M}\right.$ in THF, $0.84 \mathrm{ml}, 3.55 \mathrm{mmol}, 2.1 \mathrm{eq}$.) was added at $-20^{\circ} \mathrm{C}$ to a solution of 4-iodoanisole $(0.4 \mathrm{~g}, 1.69 \mathrm{mmol}, 1 \mathrm{eq}$. $)$ in dry THF $(10 \mathrm{ml})$. After $1 \mathrm{~h}$ of stirring at $-20^{\circ} \mathrm{C}$, a solution of ketone precursor $7 \mathrm{~b}(0.5 \mathrm{~g}$, $1.69 \mathrm{mmol})$ in dry THF $(3 \mathrm{ml})$ was slowly added. The temperature was allowed to come back to room temperature and the mixture stirred overnight. The reaction was quenched by addition of sodium bicarbonate ( $20 \%$ aq. soln., $50 \mathrm{ml})$, then extracted with ethyl acetate $(3 \times 50 \mathrm{ml})$. The combined organic layers were dried over magnesium sulfate, the solvent evaporated under reduced pressure. The crude product was purified by flash chromatography (Cy / EtOAc 8/2) to deliver the addition product (25\%) along with recovery of the starting material (50\%). The obtained alcohol $(0.1 \mathrm{~g}, 0.25 \mathrm{mmol}, 1$ eq.) was subsequently dissolved in dry DCM $(2 \mathrm{ml})$, then the mixture was cooled to $-78^{\circ} \mathrm{C}$ before slowly adding boron tribromide ( $1 \mathrm{M}$ in DCM, $0.3 \mathrm{ml}, 0.3 \mathrm{mmol}, 1.2 \mathrm{eq}$.). The reaction was continued at low temperature for $1 \mathrm{~h}$, and then quenched with sodium bicarbonate (20\% aq. soln., $10 \mathrm{ml})$. The organic materials were extracted with DCM $(3 \times 10 \mathrm{ml})$, the combined organic layers dried over magnesium sulfate and the crude product purified by flash-chromatography (PE / EtOAc $15 / 5)$ to deliver the dehydrated product $10 \mathrm{c}(85 \%)$.

$\mathrm{C}_{25} \mathrm{H}_{23} \mathrm{FN}_{2} \mathrm{O}$; White solid; $\mathrm{Mp}=126-128{ }^{\circ} \mathrm{C}$; Yield: $20 \%$ (over two steps); $\mathrm{M}=386.46 \mathrm{~g} / \mathrm{mol}$; IR (ZnSe) v $=2933,1609$, 1517, 1284, 1247, $838 \mathrm{~cm}^{-1} ;{ }^{1} \mathrm{H}$ NMR $\left(300 \mathrm{MHz}, \mathrm{CDCl}_{3}\right) \delta 1.69-1.77(\mathrm{~m}, 3 \mathrm{H}), 1.85-1.93(\mathrm{~m}, 1 \mathrm{H}), 2.21-2.26(\mathrm{~m}, 2 \mathrm{H}), 2.58$ $(\mathrm{d}, J=16.3 \mathrm{~Hz}, 1 \mathrm{H}), 3.07(\mathrm{~d}, J=16.3 \mathrm{~Hz}, 1 \mathrm{H}), 3.76(\mathrm{~s}, 3 \mathrm{H}), 5.90(\mathrm{t}, J=3.9 \mathrm{~Hz}, 1 \mathrm{H}), 6.06(\mathrm{~d}, J=10.0 \mathrm{~Hz}, 1 \mathrm{H}), 6.41(\mathrm{~d}, J$ $=10.0 \mathrm{~Hz}, 1 \mathrm{H}), 6.77(\mathrm{~d}, J=8.8 \mathrm{~Hz}, 2 \mathrm{H}), 7.12-7.18(\mathrm{~m}, 1 \mathrm{H}), 7.22(\mathrm{~d}, J=8.8 \mathrm{~Hz}, 2 \mathrm{H}), 7.33(\mathrm{~s}, 1 \mathrm{H}), 7.41-7.46(\mathrm{~m}, 2 \mathrm{H}) ;{ }^{13} \mathrm{C}$ $\operatorname{NMR}\left(75 \mathrm{MHz}, \mathrm{CDCl}_{3}\right) \delta 18.3\left(\mathrm{CH}_{2}\right), 26.2\left(\mathrm{CH}_{2}\right), 30.7\left(\mathrm{CH}_{2}\right), 35.9\left(\mathrm{CH}_{2}\right), 41.0\left(\mathrm{C}_{\mathrm{q}}\right), 55.3\left(\mathrm{CH}_{3}\right), 113.2(2 \mathrm{CH}), 113.8(\mathrm{CH})$, 
$115.5\left(\mathrm{C}_{\mathrm{q}}\right), 116.0(\mathrm{CH}), 116.3(\mathrm{CH}), 125.3(\mathrm{CH}), 125.4(\mathrm{CH}), 127.9(\mathrm{CH}), 129.8(2 \mathrm{CH}), 135.2\left(\mathrm{C}_{\mathrm{q}}\right), 136.0\left(\mathrm{C}_{\mathrm{q}}\right), 138.4(\mathrm{CH})$, $140.9(\mathrm{CH}), 143.4\left(\mathrm{C}_{q}\right), 158.2\left(\mathrm{C}_{q}\right), 160.0\left(\mathrm{C}_{q}\right), 163.2\left(\mathrm{C}_{q}\right)$; HRMS: calcd. for $\mathrm{C}_{25} \mathrm{H}_{24} \mathrm{FN}_{2} \mathrm{O}$ 387.18672, found 387.18647 ($0.641 \mathrm{ppm})$.

\subsubsection{6'-benzyl-1-(4-fluorophenyl)spiro[4H-indazole-5,2'-cyclo-hexane]-1'-one (11a)}

Under nitrogen atmosphere and at low temperature $\left(-78^{\circ} \mathrm{C}\right)$, LHMDS (1M soln, in THF, $\left.0.7 \mathrm{ml}, 0.67 \mathrm{mmol}, 1 \mathrm{eq}.\right)$ and then DMPU ( $0.1 \mathrm{ml}, 0.84 \mathrm{mmol}, 1.2 \mathrm{eq}$.) were subsequently added to a solution of the starting ketone $7 \mathbf{b}(0.2 \mathrm{~g}, 0.67 \mathrm{mmol}, 1$ eq.) in dry THF (5 ml). The mixture was stirred at low temperature for $1 \mathrm{~h}$, prior to addition of benzyl bromide $(0.08 \mathrm{ml}$, $0.67 \mathrm{mmol}, 1$ eq.). The reaction was allowed to slowly come back to room temperature over $12 \mathrm{~h}$ under stirring, then quenched by addition of water $(10 \mathrm{ml})$. The organic materials were extracted with ethyl acetate $(3 \times 10 \mathrm{ml})$ and subsequently concentrated under vacuum. The crude product was purified by flash-chromatography (PE / AcOEt 9 / 1). The dibenzylated product was eluted first followed by the mono-benzylated derivative as a mixture of $2 / 1$ diastereoisomers.

(as indicated by H-NMR, mixture of diastereoisomers A/B 2/1): $\mathrm{C}_{25} \mathrm{H}_{23} \mathrm{FN}_{2} \mathrm{O}$; colorless visc. oil; yield 14\%, $\mathrm{M}=386.46 \mathrm{~g}$ / mol; IR (ZnSe) $v=2937,1711,1517,1225,1083 \mathrm{~cm}^{-1}$; ${ }^{1} \mathrm{H}$ NMR (300 MHz, $\left.\mathrm{CDCl}_{3}\right) \delta 1.49-2.12(\mathrm{~m}, 8 \mathrm{H}), 2.39-2.49(\mathrm{~m}$, 2.5H), 2.79-3.05 (m, 2H), 3.16-3.28 (m, 2H), $3.45\left(\mathrm{~d}, J=16.2 \mathrm{~Hz}, 1 \mathrm{H}_{\mathrm{A}}\right), 6.14\left(\mathrm{~d}, J=10.0 \mathrm{~Hz}, 1 \mathrm{H}_{\mathrm{A}}\right), 6.20(\mathrm{~d}, J=10.1 \mathrm{~Hz}$, $\left.1 \mathrm{H}_{\mathrm{B}}\right), 6.48\left(\mathrm{~d}, J=10.1 \mathrm{~Hz}, 1 \mathrm{H}_{\mathrm{B}}\right), 6.50\left(\mathrm{~d}, \mathrm{~J}=10.0 \mathrm{~Hz}, 1 \mathrm{H}_{\mathrm{A}}\right), 7.12-7.31(\mathrm{~m}, 10 \mathrm{H}), 7.39-7.48(\mathrm{~m}, 4 \mathrm{H}) ;{ }^{13} \mathrm{C} \mathrm{NMR}(75 \mathrm{MHz}$, $\left.\mathrm{CDCl}_{3}\right) \delta$ for major diastereoisomer A: $21.5\left(\mathrm{CH}_{2}\right), 28.0\left(\mathrm{CH}_{2}\right), 34.8\left(\mathrm{CH}_{2}\right), 35.7\left(\mathrm{CH}_{2}\right), 41.1\left(\mathrm{CH}_{2}\right), 48.6(\mathrm{CH}), 52.1\left(\mathrm{C}_{\mathrm{q}}\right)$, $116.1(\mathrm{CH}), 116.4(\mathrm{CH}), 116.9\left(\mathrm{C}_{\mathrm{q}}\right), 117.2(\mathrm{CH}), 125.1(\mathrm{CH}), 125.3(\mathrm{CH}), 126.1(\mathrm{CH}), 128.4(2 \mathrm{CH}), 129.2(2 \mathrm{CH}), 130.5$ $(\mathrm{CH}), 135.6\left(\mathrm{C}_{\mathrm{q}}\right), 138.1(\mathrm{CH}), 140.5\left(\mathrm{C}_{\mathrm{q}}\right), 160.1\left(\mathrm{C}_{\mathrm{q}}\right), 163.3\left(\mathrm{C}_{\mathrm{q}}\right), 210.5\left(\mathrm{C}_{\mathrm{q}}\right) ; \mathrm{MS} \mathrm{m} / \mathrm{z}=387.3[\mathrm{M}+\mathrm{H}]^{+}$; HRMS: calcd. for $\mathrm{C}_{25} \mathrm{H}_{24} \mathrm{FN}_{2} \mathrm{O} 387.18672$, found 387.18806 (3.466 ppm).

4.2.17 6',6'-dibenzyl-1-(4-fluorophenyl)spiro[4H-indazole-5,2'-cyclohexane]-1'-one (12a)

The title compound was obtained during the synthesis of the compound 11a as indicated above.

$\mathrm{C}_{32} \mathrm{H}_{29} \mathrm{FN}_{2} \mathrm{O}$; white solid; m.p. 188-190C Yield: $14 \%$; $\mathrm{M}=476.58 \mathrm{~g} / \mathrm{mol}$; IR (ZnSe) $v=2933,1689,1517,1222,1079$, $838 \mathrm{~cm}^{-1} ;{ }^{1} \mathrm{H}$ NMR $\left(300 \mathrm{MHz}, \mathrm{CDCl}_{3}\right) \delta 1.48-1.55(\mathrm{~m}, 1 \mathrm{H}), 1.67-1.89(\mathrm{~m}, 5 \mathrm{H}), 2.52(\mathrm{~d}, J=13.2 \mathrm{~Hz}, 1 \mathrm{H}), 2.64(\mathrm{~d}, J=6.3$ $\mathrm{Hz}, 1 \mathrm{H}), 2.69(\mathrm{~d}, J=8.8 \mathrm{~Hz}, 1 \mathrm{H}), 2.96(\mathrm{~d}, J=15.7 \mathrm{~Hz}, 1 \mathrm{H}), 3.23(\mathrm{~d}, J=13.2 \mathrm{~Hz}, 1 \mathrm{H}), 3.35(\mathrm{~d}, J=13.2 \mathrm{~Hz}, 1 \mathrm{H}), 5.54(\mathrm{~d}$, $J=10.0 \mathrm{~Hz}, 1 \mathrm{H}), 6.36(\mathrm{~d}, J=10.0 \mathrm{~Hz}, 1 \mathrm{H}), 7.08-7.16(\mathrm{~m}, 6 \mathrm{H}), 7.20-7.33(\mathrm{~m}, 6 \mathrm{H}), 7.39-7.44(\mathrm{~m}, 3 \mathrm{H}) ;{ }^{13} \mathrm{C} \mathrm{NMR}(75 \mathrm{MHz}$, $\left.\mathrm{CDCl}_{3}\right) \delta 16.4\left(\mathrm{CH}_{2}\right), 29.1\left(\mathrm{CH}_{2}\right), 29.4\left(\mathrm{CH}_{2}\right), 32.2\left(\mathrm{CH}_{2}\right), 43.9\left(\mathrm{CH}_{2}\right), 44.4\left(\mathrm{CH}_{2}\right), 51.0\left(\mathrm{C}_{\mathrm{q}}\right), 54.5\left(\mathrm{C}_{\mathrm{q}}\right), 113.8\left(\mathrm{C}_{\mathrm{q}}\right), 115.2$ $(\mathrm{CH}), 116.1(\mathrm{CH}), 116.4(\mathrm{CH}), 125.1(\mathrm{CH}), 125.2(\mathrm{CH}), 126.6(\mathrm{CH}), 126.8(\mathrm{CH}), 128.2(2 \mathrm{CH}), 128.2(2 \mathrm{CH}), 131.3(2 \mathrm{CH})$, $131.3(2 \mathrm{CH}), 134.2(\mathrm{CH}), 135.9\left(\mathrm{C}_{\mathrm{q}}\right), 137.1\left(\mathrm{C}_{\mathrm{q}}\right), 137.8\left(\mathrm{C}_{\mathrm{q}}\right), 138.3(\mathrm{CH}), 160.0\left(\mathrm{C}_{\mathrm{q}}\right), 163.3\left(\mathrm{C}_{\mathrm{q}}\right), 217.4\left(\mathrm{C}_{\mathrm{q}}\right)$; HRMS: calcd. for $\mathrm{C}_{32} \mathrm{H}_{30} \mathrm{FN}_{2} \mathrm{O}$ 477.23367, found 477.23231 (-2.846 ppm).

\subsubsection{6'-benzyl-1-(4-fluorophenyl)spiro[4H-indazole-5,2'-cyclohexane]-1'-ol (13a)}

Under inert atmosphere and at $-78^{\circ} \mathrm{C}$, DIBAL-H (1M soln. in cyclohexane, $0.23 \mathrm{ml}, 0.23 \mathrm{mmol}, 3$ eq.) was slowly added to a solution of the starting ketone 11a $(0.03 \mathrm{~g}, 0.08 \mathrm{mmol}, 1 \mathrm{eq}$.) in dry THF $(3 \mathrm{ml})$. The mixture was stirred at low temperature for $2 \mathrm{~h}$, then, after the complete consumption of the starting material, the reaction was quenched with water $(10 \mathrm{ml})$. The organics were extracted with ethyl acetate $(3 \times 10 \mathrm{ml})$ and the combined organic layers were concentrated under vacuum. The crude product was purified by flash-chromatography (PE / EtOAc 7/3) to give the desired alcohol.

$\mathrm{C}_{25} \mathrm{H}_{25} \mathrm{FN}_{2} \mathrm{O}$; White solid; $\mathrm{Mp}=203-20{ }^{\circ} \mathrm{C}$; Yield: $77 \%$; $\mathrm{M}=388.48 \mathrm{~g} / \mathrm{mol}$; IR $(\mathrm{ZnSe}) v=3342,2922,1517,1218,992$ $\mathrm{cm}^{-1} ;{ }^{1} \mathrm{H}$ NMR $\left(300 \mathrm{MHz}, \mathrm{CDCl}_{3}\right) \delta 1.36-1.70(\mathrm{~m}, 7 \mathrm{H}), 1.83-1.94(\mathrm{~m}, 1 \mathrm{H}), 2.43(\mathrm{~d}, J=16.0 \mathrm{~Hz}, 1 \mathrm{H}), 2.55-2.70(\mathrm{~m}, 2 \mathrm{H})$, $2.92(\mathrm{~d}, J=16.0 \mathrm{~Hz}, 1 \mathrm{H}), 3.41(\mathrm{~s}, 1 \mathrm{H}), 6.06(\mathrm{~d}, J=10.1 \mathrm{~Hz}, 1 \mathrm{H}), 6.38(\mathrm{~d}, J=10.1 \mathrm{~Hz}, 1 \mathrm{H}), 7.12-7.24(\mathrm{~m}, 7 \mathrm{H}), 7.32-7.39$ $(\mathrm{m}, 3 \mathrm{H}) ;{ }^{13} \mathrm{C}$ NMR $\left(75 \mathrm{MHz}, \mathrm{CDCl}_{3}\right) \delta 21.5\left(\mathrm{CH}_{2}\right), 25.4\left(\mathrm{CH}_{2}\right), 29.7\left(\mathrm{CH}_{2}\right), 30.5\left(\mathrm{CH}_{2}\right), 39.8\left(\mathrm{CH}_{2}\right), 40.5(\mathrm{CH}), 41.2\left(\mathrm{C}_{\mathrm{q}}\right)$, $71.9(\mathrm{CH}), 115.8(\mathrm{CH}), 115.8\left(\mathrm{C}_{\mathrm{q}}\right), 116.1(\mathrm{CH}), 116.4(\mathrm{CH}), 125.1(\mathrm{CH}), 125.2(\mathrm{CH}), 126.0(\mathrm{CH}), 128.4(2 \mathrm{CH}), 129.1$ $(2 \mathrm{CH}), 135.7(\mathrm{CH}), 137.2\left(\mathrm{C}_{\mathrm{q}}\right), 138.3(\mathrm{CH}), 140.8\left(\mathrm{C}_{\mathrm{q}}\right), 163.3\left(\mathrm{C}_{\mathrm{q}}\right)$; HRMS: calcd. for $\mathrm{C}_{25} \mathrm{H}_{26} \mathrm{FN}_{2} \mathrm{O}$ 389.20237, found 389.20147 (-2.31 ppm).

\subsubsection{6',6'-dibenzyl-1-(4-fluorophenyl)spiro[4H-indazole-5,2'-cyclohexane]-1'-ol (14a)}

Under inert atmosphere and at $0^{\circ} \mathrm{C}, \mathrm{LiAlH}_{4}(0.01 \mathrm{~g}, 0.23 \mathrm{mmol}, 1.2 \mathrm{eq}$.) was added in one portion to a mixture of the starting ketone $12 \mathrm{a}\left(0.09 \mathrm{~g}, 0.19 \mathrm{mmol}, 1\right.$ eq.) in dry THF $(3 \mathrm{ml})$. The mixture was stirred for $2 \mathrm{~h}$ at $0^{\circ} \mathrm{C}$, and then the reaction was quenched by addition of water $(1 \mathrm{ml})$. After dilution with ethyl acetate $(10 \mathrm{ml})$, the precipitated salts were filtrated on a celite pad. Water was subsequently added $(10 \mathrm{ml})$ and the organics were extracted with ethyl acetate $(3 \mathrm{x} 10 \mathrm{ml})$. The combined organic layers were dried over magnesium sulfate and concentrated under vacuum. The crude product was purified by flashchromatography (PE / EtOAc 8/2) to conduct to the desired alcohol.

$\mathrm{C}_{32} \mathrm{H}_{31} \mathrm{FN}_{2} \mathrm{O}$; White solid; $\mathrm{Mp}=124-126^{\circ} \mathrm{C}$; Yield: $56 \%$; $\mathrm{M}=478.60 \mathrm{~g} / \mathrm{mol}$; IR (ZnSe) $v=3390,2933,1517,1225,1072$ $\mathrm{cm}^{-1} ;{ }^{1} \mathrm{H}$ NMR $\left(300 \mathrm{MHz}, \mathrm{CDCl}_{3}\right) \delta 0.88(\mathrm{td}, J=13.3 \mathrm{~Hz}, J=4.0 \mathrm{~Hz}, 1 \mathrm{H}), 1.14(\mathrm{td}, J=13.7 \mathrm{~Hz}, J=3.1 \mathrm{~Hz}, 1 \mathrm{H}), 1.36-$ $1.43(\mathrm{~m}, 1 \mathrm{H}), 1.48(\mathrm{~d}, J=3.5 \mathrm{~Hz}, 1 \mathrm{H}), 1.64(\mathrm{dd}, J=14.0 \mathrm{~Hz}, J=2.3 \mathrm{~Hz}, 1 \mathrm{H}), 1.81(\mathrm{dd}, J=13.7 \mathrm{~Hz}, J=2.4 \mathrm{~Hz}, 1 \mathrm{H}), 1.88-$ 
$2.05(\mathrm{~m}, 1 \mathrm{H}), 2.05(\mathrm{~d}, J=13.2 \mathrm{~Hz}, 1 \mathrm{H}), 2.98-3.31(\mathrm{~m}, 4 \mathrm{H}), 3.38(\mathrm{~d}, J=3.2 \mathrm{~Hz}, 1 \mathrm{H}), 5.34(\mathrm{~d}, J=10.0 \mathrm{~Hz}, 1 \mathrm{H}), 6.42(\mathrm{~d}, J$ $=10.0 \mathrm{~Hz}, 1 \mathrm{H}), 7.10-7.32(\mathrm{~m}, 12 \mathrm{H}), 7.40,7.46(\mathrm{~m}, 3 \mathrm{H}) ;{ }^{13} \mathrm{C} \mathrm{NMR}\left(75 \mathrm{MHz}, \mathrm{CDCl}_{3}\right) \delta 16.4\left(\mathrm{CH}_{2}\right), 23.0\left(\mathrm{CH}_{2}\right), 29.9\left(\mathrm{CH}_{2}\right)$, $33.0\left(\mathrm{CH}_{2}\right), 37.4\left(\mathrm{CH}_{2}\right), 42.9\left(\mathrm{C}_{\mathrm{q}}\right), 43.1\left(\mathrm{CH}_{2}\right), 44.6\left(\mathrm{C}_{\mathrm{q}}\right), 77.9(\mathrm{CH}), 115.1\left(\mathrm{C}_{\mathrm{q}}\right), 116.1(\mathrm{CH}), 116.4(\mathrm{CH}), 116.4(\mathrm{CH}), 125.3$ $(\mathrm{CH}), 125.4(\mathrm{CH}), 126.2(\mathrm{CH}), 126.2(\mathrm{CH}), 127.9(2 \mathrm{CH}), 128.1(2 \mathrm{CH}), 131.4(2 \mathrm{CH}), 131.4(2 \mathrm{CH}), 135.5\left(\mathrm{C}_{\mathrm{q}}\right), 138.4\left(\mathrm{C}_{\mathrm{q}}\right)$, $138.7\left(\mathrm{C}_{\mathrm{q}}\right), 139.0(\mathrm{CH}), 141.3(\mathrm{CH})$; HRMS: calcd. for $\mathrm{C}_{32} \mathrm{H}_{32} \mathrm{FN}_{2} \mathrm{O} 479.249318$, found 479.24958 (0.55 ppm).

\subsubsection{1-(4-fluorophenyl)-6'-prop-2-ynyl-spiro[4H-indazole-5,2'-cyclohexane]-1'-one (11b)}

Under inert atmosphere, LDA (2M soln. in THF, $0.44 \mathrm{ml}, 0.88 \mathrm{mmol}, 1.3 \mathrm{eq}$.) was slowly added at $-78^{\circ} \mathrm{C}$ to a solution of ketone $7 \mathbf{b}(0.2 \mathrm{~g}, 0.67 \mathrm{mmol}, 1$ eq. $)$ in dry THF $(6 \mathrm{ml})$. After $1 \mathrm{~h}$ of reaction at low temperature, propargyl bromide $(80 \%$ soln. in toluene, $0.11 \mathrm{ml}, 1.01 \mathrm{mmol}, 1.5 \mathrm{eq}$.) was added and the reaction allowed to slowly come back to room temperature over $12 \mathrm{~h}$ under stirring. The reaction was quenched by addition of water $(10 \mathrm{ml})$ and the organic materials extracted with ethyl acetate $(2 \times 20 \mathrm{ml})$. The combined organic layers were dried over magnesium sulfate and concentrated under vacuum to give a crude product further purified by flash-chromatography (PE / EtOAc 9/1).

$\mathrm{C}_{21} \mathrm{H}_{19} \mathrm{FN}_{2} \mathrm{O}$; Light yellow visq oil; Yield: $18 \%$; $\mathrm{M}=336.40 \mathrm{~g} / \mathrm{mol}$; IR (ZnSe) $v=2937,1711,1517,1225,846$

$\mathrm{cm}^{-1} ;{ }^{1} \mathrm{H}$ NMR $\left(300 \mathrm{MHz}, \mathrm{CDCl}_{3}\right) \delta$ 1.35-1.66 (m, 3H), 1.73-1.82 (m, 1H), 1.94-2.06 (m, 2H), 2.15-2.25 (m, $\left.2 \mathrm{H}\right), 2.45$ $(\mathrm{d}, J=16.2 \mathrm{~Hz}, 1 \mathrm{H}), 2.45-2.62(\mathrm{~m}, 2 \mathrm{H}), 2.91-3.02(\mathrm{~m}, 1 \mathrm{H}), 3.42(\mathrm{~d}, J=16.2 \mathrm{~Hz}, 1 \mathrm{H}), 6.12(\mathrm{~d}, J=10.0 \mathrm{~Hz}, 1 \mathrm{H}), 6.52$ $(\mathrm{d}, J=10.0 \mathrm{~Hz}, 1 \mathrm{H}), 7.11-7.17(\mathrm{~m}, 2 \mathrm{H}), 7.40-7.46(\mathrm{~m}, 3 \mathrm{H}) ;{ }^{13} \mathrm{C} \mathrm{NMR}\left(75 \mathrm{MHz}, \mathrm{CDCl}_{3}\right) \delta 19.2\left(\mathrm{CH}_{2}\right), 21.3\left(\mathrm{CH}_{2}\right)$, $27.9\left(\mathrm{CH}_{2}\right), 34.5\left(\mathrm{CH}_{2}\right), 40.9\left(\mathrm{CH}_{2}\right), 45.9(\mathrm{CH}), 51.9\left(\mathrm{C}_{\mathrm{q}}\right), 69.7(\mathrm{CH}), 82.7\left(\mathrm{C}_{\mathrm{q}}\right), 116.1(\mathrm{CH}), 116.4(\mathrm{CH}), 116.8\left(\mathrm{C}_{\mathrm{q}}\right)$, $117.5(\mathrm{CH}), 125.1(\mathrm{CH}), 125.3(\mathrm{CH}), 130.0(\mathrm{CH}), 135.5\left(\mathrm{C}_{\mathrm{q}}\right), 138.0(\mathrm{CH}), 160.0\left(\mathrm{C}_{\mathrm{q}}\right), 163.3\left(\mathrm{C}_{\mathrm{q}}\right)$; HRMS: calcd. for $\mathrm{C}_{21} \mathrm{H}_{19} \mathrm{FN}_{2} \mathrm{NaO} 357.13736$, found 357.13660 (-2.14 ppm).

\subsubsection{1-(4-fluorophenyl)-6'-prop-2-ynyl-spiro[4H-indazole-5,2'-cyclohexane]-1'-ol (13b)}

The title compound was obtained following the same experimental protocol used for the synthesis of compound 13a starting from $0.05 \mathrm{~g}$ of the corresponding ketone.

$\mathrm{C}_{21} \mathrm{H}_{21} \mathrm{FN}_{2} \mathrm{O}$; White solid; $\mathrm{Mp}=173-175^{\circ} \mathrm{C}$; Yield: $18 \%$; $=336.40 \mathrm{~g} / \mathrm{mol}$; IR $(\mathrm{ZnSe}) v=3302,2930,1517,1225 \mathrm{~cm}^{-}$ ${ }^{1} ;{ }^{1} \mathrm{H}$ NMR $\left(300 \mathrm{MHz}, \mathrm{CDCl}_{3}\right) \delta 1.39-1.68(\mathrm{~m}, 5 \mathrm{H}), 1.93(\mathrm{t}, J=2.7 \mathrm{~Hz}, 1 \mathrm{H}), 2.11(\mathrm{~d}, J=5.8 \mathrm{~Hz}, 1 \mathrm{H}), 2.19(\mathrm{t}, J=2.6 \mathrm{~Hz}$, $1 \mathrm{H}), 2.22(\mathrm{t}, J=3.0 \mathrm{~Hz}, 1 \mathrm{H}), 2.42(\mathrm{~d}, J=16.0 \mathrm{~Hz}, 1 \mathrm{H}), 2.96(\mathrm{~d}, J=16.0 \mathrm{~Hz}, 1 \mathrm{H}), 3.64(\mathrm{~d}, J=5.2 \mathrm{~Hz}, 1 \mathrm{H}), 6.09(\mathrm{~d}, J=$ $10.1 \mathrm{~Hz}, 1 \mathrm{H}), 6.45(\mathrm{~d}, J=10.1 \mathrm{~Hz}, 1 \mathrm{H}), 7.13-7.19(\mathrm{~m}, 2 \mathrm{H}), 7.38(\mathrm{~s}, 1 \mathrm{H}), 7.42-7.47(\mathrm{~m}, 2 \mathrm{H}) ;{ }^{13} \mathrm{C} \mathrm{NMR}(75 \mathrm{MHz}, \mathrm{CDCl})_{3} \delta$ $21.3\left(\mathrm{CH}_{2}\right), 22.8\left(\mathrm{CH}_{2}\right), 25.3\left(\mathrm{CH}_{2}\right), 29.6\left(\mathrm{CH}_{2}\right), 30.2\left(\mathrm{CH}_{2}\right), 38.2(\mathrm{CH}), 41.2\left(\mathrm{C}_{\mathrm{q}}\right), 69.6(\mathrm{CH}), 71.5(\mathrm{CH}), 83.4\left(\mathrm{C}_{\mathrm{q}}\right), 115.9$ $\left(\mathrm{C}_{\mathrm{q}}\right), 115.9(\mathrm{CH}), 116.1(\mathrm{CH}), 116.4(\mathrm{CH}), 125.0(\mathrm{CH}), 125.1(\mathrm{CH}), 135.5(\mathrm{CH}), 137.2\left(\mathrm{C}_{\mathrm{q}}\right), 138.3(\mathrm{CH}), 160.0\left(\mathrm{C}_{\mathrm{q}}\right), 163.3$ $\left(\mathrm{C}_{\mathrm{q}}\right)$; HRMS: calcd. for $\mathrm{C}_{21} \mathrm{H}_{22} \mathrm{FN}_{2} \mathrm{O} 337.171068$, found 337.17086 (-0.62 ppm). 